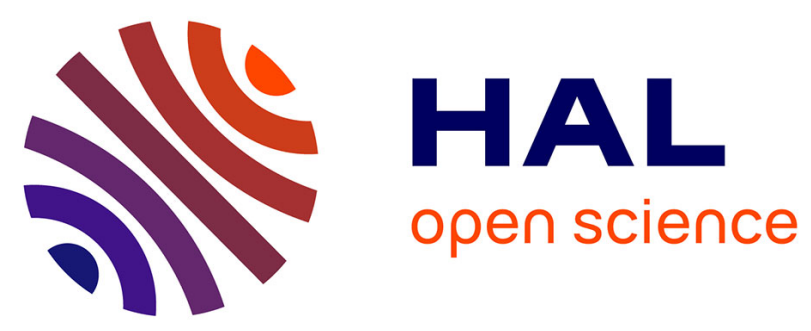

\title{
Effects of chelators on the structure and electrochemical properties of Li-rich Li1.2Ni0.13Co0.13Mn0.54O2 cathode materials
}

\author{
A. Abdel-Ghany, A. M Hashem, A. Mauger, C.M. Julien
}

\section{- To cite this version:}

A. Abdel-Ghany, A. M Hashem, A. Mauger, C.M. Julien. Effects of chelators on the structure and electrochemical properties of Li-rich Li1.2Ni0.13Co0.13Mn0.54O2 cathode materials. Journal of Solid State Electrochemistry, 2020, 24 (11-12), pp.3157-3172. 10.1007/s10008-020-04789-7 . hal-03014158

\section{HAL Id: hal-03014158 \\ https://hal.sorbonne-universite.fr/hal-03014158}

Submitted on 19 Nov 2020

HAL is a multi-disciplinary open access archive for the deposit and dissemination of scientific research documents, whether they are published or not. The documents may come from teaching and research institutions in France or abroad, or from public or private research centers.
L'archive ouverte pluridisciplinaire HAL, est destinée au dépôt et à la diffusion de documents scientifiques de niveau recherche, publiés ou non, émanant des établissements d'enseignement et de recherche français ou étrangers, des laboratoires publics ou privés. 


\title{
Effects of chelators on the structure and electrochemical properties of Li-rich $\mathrm{Li}_{1.2} \mathrm{Ni}_{0.13} \mathrm{Co}_{0.13} \mathrm{Mn}_{0.54} \mathrm{O}_{2}$ cathode materials
}

\author{
A. E. Abdel-Ghany ${ }^{1}$, A. M. Hashem¹, A. Mauger², C.M. Julien² \\ ${ }^{1}$ National Research Centre, Inorganic Chemistry Department, 33 El Bohouth St. (former El \\ Tahrir St.), Dokki-Giza 12622, Egypt \\ ${ }^{2}$ Institut de Minéralogie, de Physique des Matériaux et Cosmologie (IMPMC), Sorbonne \\ Université, UMR-CNRS 7590, 4 place Jussieu, 75752 Paris, France
}

\begin{abstract}
In this study, carboxylic acids, namely concentrated citric acid and ethylene diamine tetra-acetic acid (EDTA) solution, are used as chelators to synthesize Li-rich layered $\mathrm{Li}_{1.2} \mathrm{Ni}_{0.13} \mathrm{Mn}_{0.54} \mathrm{Co}_{0.13} \mathrm{O}_{2}$ (LLNMC) by sol-gel method. We investigate the influence of these chelators on the morphology crystal properties, and electrochemical performance of LNMC. Based on XRD data, the synthesized materials can be characterized as a combination of two phases, a rhombohedral $R \overline{3} m$ phase $\left(\mathrm{LiNi}_{1 / 3} \mathrm{Mn}_{1 / 3} \mathrm{Co}_{1 / 3} \mathrm{O}_{2}\right)$ and a monoclinic $C 2 / m$ phase $\left(\mathrm{Li}_{2} \mathrm{MnO}_{3}\right)$, which, according to the stoichiometry, are $x \mathrm{Li}_{2} \mathrm{MnO}_{3} \cdot(1 \mathrm{x}) \mathrm{LiNi}_{1 / 3} \mathrm{Mn}_{1 / 3} \mathrm{Co}_{1 / 3} \mathrm{O}_{2}$ with $x=0.5$. The morphology and local structure were studied using electron microscopy (SEM, TEM and HRTEM) and Raman spectroscopy, respectively. A clear evidence for the effect of chelating agent was observed from electrochemical tests carried out by galvanostatic charge-discharge cycling and electrochemical impedance spectroscopy. The sample prepared via EDTA as organic complexing agent exhibits the best electrochemical properties, with higher capacity and rate capability.
\end{abstract}

Keywords: Chelating agent; Li-rich cathode; Lithium-ion batteries; Electrochemical impedance 


\section{Introduction}

The lithium-ion batteries (LIBs) are considered as a key product to the progressive replacement of fossil energy by green energy. Their use in some applications require ever growing energy densities, for instance to increase the driving range of electric vehicles. To satisfy this purpose, intense research is currently done on advanced positive electrode materials, since they are limiting components of LIBs [1,2]. In particular, layered lithiumrich oxides, represented by $x \mathrm{Li}_{2} \mathrm{MnO}_{3} \cdot(1 x) \mathrm{LiNi}_{\mathrm{x}} \mathrm{Mn}_{\mathrm{y}} \mathrm{Co}_{1-\mathrm{x}-\mathrm{y}} \mathrm{O}_{2}$ (shorted as LLNMC) exhibit a reversible specific capacity of $\geq 250 \mathrm{mAh} \mathrm{g}^{-1}$ and wide operating voltage range (2.0-4.8 V vs. $\mathrm{Li}^{+} / \mathrm{Li}$ ) [3-7]. The performance compares well with the capacity of conventional cathode materials ( $\leq 200 \mathrm{mAh} \mathrm{g}$ ), such as $\mathrm{LiCoO}_{2}$ (LCO), $\mathrm{LiNi}_{\mathrm{x}} \mathrm{Mn}_{\mathrm{y}} \mathrm{Co}_{1-\mathrm{x}-}$ ${ }_{y} \mathrm{O}_{2}(\mathrm{NMC})$ and $\mathrm{LiNi}_{\mathrm{x}} \mathrm{Co}_{1 x y} \mathrm{Al}_{\mathrm{y}} \mathrm{O}_{2}$ (NCA). The remarkably high capacity of LLNMC is obtained when the $\mathrm{Li}_{2} \mathrm{MnO}_{3}$ component is activated, which requires a charge potential higher than $4.5 \mathrm{~V}$ [8-10]. However, this large potential leads to endangerment for its crystal structure, so that this electrode suffers from a high initial irreversible capacity loss (ICL), a low rate capability and increasing polarization upon cycle number [11]. The high ILC values are due to the extraction of lithium as $\mathrm{Li}_{2} \mathrm{O}$ followed by an elimination of oxide ion vacancies from the layered lattice involving the diffusion of cations and anions during first charge $[5,12]$. To reduce this ICL, different strategies have been proposed. One of them is the optimisation of the nano-particle morphology [13]. Another one is the surface modification. This can be achieved by coating the particles with other compounds such as $\mathrm{AlPO}_{4}$ [14], $\mathrm{AlF}_{3}$ [15], $\mathrm{FeF}_{3}$ [16], $\mathrm{V}_{2} \mathrm{O}_{5}$ [17], or $\mathrm{Al}_{2} \mathrm{O}_{3}$ [18]. Another effective strategy to reduce the oxygen release is pre-activation, which is another type of surface modification, this time by chemical reaction. Different reagents were used, including acids like $\mathrm{HNO}_{3}$ [19] and citric acid [20], but also $\mathrm{Na}_{2} \mathrm{~S}_{2} \mathrm{O}_{8},\left(\mathrm{NH}_{4}\right)_{2} \mathrm{SO}_{4}$, and $\mathrm{NH}_{4} \mathrm{H}_{2} \mathrm{SO}_{4}$ [21-23]. Deionized water also proved effective in realizing pre-activation [24]. As an extreme case, the modification can extend to the bulk of the particles by insertion of abundant nanoscale defects [25]. The difficulty in this later case is to avoid the damage of the crystal lattice, which would deteriorate the cycle ability. Acid leaching is associated with a $\mathrm{H}^{+} / \mathrm{Li}^{+}$exchange and simultaneous removal of $\mathrm{O}^{2-}$ that activates $\mathrm{Li}_{2} \mathrm{MnO}_{3}[26,27]$. 
Various synthesis methods have been used to prepare LLNMCs, such as sol-gel [11,28-31], co-precipitation [32-35]), solid state reaction [36,37], molten salt [38] and combustion [39]. Among them, the sol-gel method is the most popular to produce homogeneous and stoichiometric nano-sized materials $[13,40]$.

In the aqueous organic sol-gel route, precursors, i.e. metal acetates or metal nitrates, react with a polyfunctional acid such as citric acid to form an amorphous gel with production of stable complexes and absence of precipitation. Ethylene-diamine-tetraacetic acid (EDTA, $\left.\left(\mathrm{CH}_{2} \mathrm{~N}\right)_{2}\left(\mathrm{CH}_{2} \mathrm{COOH}\right)_{4}\right)$ is an amimo-polycarboxylic acid, which forms more stable soluble complexes with metallic elements than citric acid due to its ability to bind almost any cation. Depending on the $\mathrm{pH}$ of the aqueous solution, the four carboxylate groups of EDTA allow the molecule to behave as multi-dentate ligand. The binding ability of EDTA is generally enhanced with increasing $\mathrm{pH}[13,40]$, especially as it is triply ionized at $\mathrm{pH} 7.4$ [41]. ETDA synthesis was successfully used to prepare a variety of oxides for $\mathrm{LIBs}$, such as $\mathrm{LiV}_{3} \mathrm{O}_{8}$ [42], $\mathrm{LiNi}_{0.80} \mathrm{Co}_{0.15} \mathrm{Al}_{0.05} \mathrm{O}_{2}$ [43], and $\mathrm{Li}_{3} \mathrm{~V}_{2}\left(\mathrm{PO}_{4}\right)_{3}$ [44], $\mathrm{Li}_{4} \mathrm{Ti}_{5} \mathrm{O}_{12}$ [45], $\mathrm{Li}_{1.2} \mathrm{Mn}_{0.6-\mathrm{x}} \mathrm{Ni}_{0.2-\mathrm{x}} \mathrm{Al}_{2 \mathrm{x}} \mathrm{O}_{2}$ [46]. Recently, the EDTA technique was utilized to explore the best conditions for the production of nanoparticles of $\mathrm{LiMn}_{2} \mathrm{O}_{4}$. This synthesis has revealed many advantages such as a better control of particle morphology at temperature of $650{ }^{\circ} \mathrm{C}$, the lowest calcination process for $\mathrm{LiMn}_{2} \mathrm{O}_{4}[47]$.

$\mathrm{Li}_{1.2} \mathrm{Ni}_{0.13} \mathrm{Mn}_{0.54} \mathrm{Co}_{0.13} \mathrm{O}_{2}$ compounds belong to the family of $z \mathrm{Li}\left(\mathrm{Li}_{1 / 3} \mathrm{Mn}_{2 / 3}\right) \mathrm{O}_{2} \bullet(1 z) \mathrm{Li}\left(\mathrm{Ni}_{1 / 3} \mathrm{Mn}_{1 / 3} \mathrm{Co}_{1 / 3}\right) \mathrm{O}_{2}$ solid solutions with $z=0.5$ [48]. These materials have been fabricated by wet-chemical synthesis with the assistance of different chelators such as citric acid (CA) [49] and oxalic acid (OA) [30]. The synthesis of $\mathrm{Li}_{1.2} \mathrm{Ni}_{0.13} \mathrm{Mn}_{0.54} \mathrm{Co}_{0.13} \mathrm{O}_{2}$ assisted by oxalic acid produced abundant nano-particles and porous structures generated by gas release during the high temperature calcination process [30]. Different morphologies influenced by the precipitators such as $\mathrm{NaOH}$ and $\left(\mathrm{NH}_{4}\right)_{2} \mathrm{CO}_{3}$ were obtained for Li-rich oxides prepared via rapid nucleation and postsolvothermal method [50]. In the context of the transition-metal (TM) oxide synthesis, the formation of strong links through the carboxyl groups with a metal ion leads to the 
nucleation of nanosized particles with high degree of homogeneity [51]. But with the deterioration of the $\mathrm{CA}$ during the preparation and calcination processes its granules encapsulated randomly with carbon on the surface of the cathode, which damages the desired electrochemical properties [52]. This was a motivation to use another chelating agent such as EDTA, which in addition contains nitrogen atoms that work as fuel in internal heat production and performs a combustion reaction. Heat generated leads to acceleration in the decomposition of the remaining component that results in smaller particle size with higher homogeneity. As a result, the physicochemical properties of the powders depend importantly on the nature of chelating agent used in the sol-gel method.

In this work, a comparison of the structural and electrochemical of $\mathrm{Li}_{1.2} \mathrm{Ni}_{0.13} \mathrm{Co}_{0.13} \mathrm{Mn}_{0.54} \mathrm{O}_{2}$ powders was done by studying the effect of different chelating agents, namely CA, EDTA and CA-EDTA mixture. Another sample was fabricated via sol-gel method free of chelating agent, (self-sol-gel, SSG). We believe that a comparison and understanding of the role of different chelating agents should be helpful to design and choose suitable synthetic routes for this promising electrode material.

\section{Experimental}

\subsection{Sample synthesis}

Four $\mathrm{Li}_{1.2} \mathrm{Ni}_{0.13} \mathrm{Mn}_{0.54} \mathrm{Co}_{0.13} \mathrm{O}_{2}$ samples were prepared by a sol-gel method from an aqueous solution of metal acetates mixed. One sample was prepared by SSG route via a two-step process and three samples were fabricated using CA, EDTA and CA-EDTA. The precursor of the SSG powders was prepared via a two-step process by evaporation of two aqueous solutions: solution (1) of mixed metal acetates with $10 \%$ excess lithium (molar ratio $\mathrm{Li} / \mathrm{Ni} / \mathrm{Co} / \mathrm{Mn}=$ 1.1:0.33:0.33:0.33), and solution (2) containing $\mathrm{Li}\left(\mathrm{CH}_{3} \mathrm{COO}\right)_{2} \cdot 2 \mathrm{H}_{2} \mathrm{O}(10 \%$ excess lithium and $\mathrm{Mn}\left(\mathrm{CH}_{3} \mathrm{COO}\right)_{2} \bullet 4 \mathrm{H}_{2} \mathrm{O}$ with the molar ratio $\mathrm{Li}: \mathrm{Mn}=2.2: 1$. Each solution was stirred for $5 \mathrm{~h}$ at room temperature. Then, solution (2) was placed in water bath at $80{ }^{\circ} \mathrm{C}$ with dropwise addition

of solution (1). This mixture was evaporated continuously until it turned into brown bubble. Finally, the precursor was achieved by burning the gel in the hot plate at $250{ }^{\circ} \mathrm{C}$. The obtained powder was calcined at $800{ }^{\circ} \mathrm{C}$ for $20 \mathrm{~h}$ in air to get the final product $\mathrm{Li}_{1.2} \mathrm{Ni}_{0.13} \mathrm{Co}_{0.13} \mathrm{Mn}_{0.54} \mathrm{O}_{2}$. 
For the sol-gel samples fabricated in the presence of chelating agent, the preparation of the precursor is reported in Ref. [53]. In brief, stoichiometric amounts of metal acetates $M\left(\mathrm{CH}_{3} \mathrm{COO}\right)_{2} \bullet 4 \mathrm{H}_{2} \mathrm{O}(M=\mathrm{Ni}, \mathrm{Mn}, \mathrm{Co})$ were dissolved in distilled water and stirred continuously with an excess of $\mathrm{Li}$ acetate $(10 \%$ excess $\mathrm{Li})$. The chelating agent was drowsily added to the solution under continuous stirring for $6 \mathrm{~h}$. The molar ratio of metal/chelator was 1:1 for CA or EDTA, while metal/(CA+EDTA) was 1:1.5. After adjusting the $\mathrm{pH}$ of the solution (hence ammonia addition) at value $\sim 7-8$, the solution was evaporated at $80{ }^{\circ} \mathrm{C}$ until a viscous transparent gel was obtained which transformed in to xerogel dried in oven at $120{ }^{\circ} \mathrm{C}$ for $12 \mathrm{~h}$. The powders were calcined at $450{ }^{\circ} \mathrm{C}$ for $5 \mathrm{~h}$ then reground and calcined again at $800{ }^{\circ} \mathrm{C}$ for $20 \mathrm{~h}$ in air to obtain the final products.

\subsection{Methods}

The structure of the samples was investigated using X-ray diffractometer (XRD) (model Philips X'Pert) using nickel-filtered $\mathrm{Cu}-\mathrm{K} \alpha$ radiation $(\lambda=0.15406 \mathrm{~nm})$. The diffractograms were taken at room temperature in the $2 \theta$-range of $10-80^{\circ}$. The specific area of as-prepared powders was determined by Brunauer-Emmett-Teller (BET) from $\mathrm{N}_{2}$ adsorption at $77 \mathrm{~K}$ in the relative pressure range of $0.05 \leq\left(\mathrm{p} / \mathrm{p}_{0}\right) \leq 0.30$, using an Autosorb-iQ apparatus (Quantachrome, Germany). The morphology and composition of the samples were investigated by scanning electron microscopy ZEISS model ULTRA 55, equipped with an energy-dispersive X-ray spectrometer (EDX). High-resolution transmission electron microscopy (HRTEM) images were obtained using an electronic microscope JEOL model JEM-2010. Raman spectra were recorded with a micro-Raman spectrophotometer (Horiba) coupled with an optical microscope with $100 \times$ objective and a $633 \mathrm{~nm}$ He-Ne laser excitation source. Measurements were carried out at acquisition time of $30 \mathrm{~s}$. Care was taken against sample photo-decomposition using a low excitation power $100 \mathrm{~W} \mathrm{~cm}^{-2}$. The Raman peak at $520 \mathrm{~cm}^{-1}$ of a silicon crystal was used as reference for the wavenumber calibration. Electrochemical tests were performed on CR2025type coin cells. The positive electrode was made by mixing $80 \mathrm{wt} \%$ active material, $10 \mathrm{wt} \%$ carbon black as conductive material and $10 \mathrm{wt} . \%$ polyvinylidene fluoride (PVdF) in N-methyl pyrrolidinone (NMP) solvent to form a homogeneous slurry. This slurry was then spread onto an 
aluminium foil current collector and dried at $80{ }^{\circ} \mathrm{C}$ for $2 \mathrm{~h}$ to remove the solvent before being pressed. The cathode loading was $3.5 \mathrm{mg} \mathrm{cm}^{-2}$. The electrode film was punched in the form of disks, typically with a diameter of $10 \mathrm{~mm}$, and then dried at $80{ }^{\circ} \mathrm{C}$ for $12 \mathrm{~h}$ under vacuum. The cells including lithium sheet as the counter electrode, Celgard 2500 or 2300 film as the separator, and $1 \mathrm{~mol} \mathrm{~L}^{-1} \mathrm{LiPF}_{6}$ in a mixture of ethylene carbonate (EC)/dimethyl carbonate (DEC) (1:1) solution (LP30, Merk) as electrolyte were assembled in a glove box (moisture and oxygen content $\leq 5 \mathrm{ppm}$ ) under argon atmosphere. The galvanostatic charge-discharge curves were performed using a potentiostat/galvanostat (VMP3 Bio-Logic) in the potential range 2.0-4.8 V. Electrochemical impedance spectroscopy (EIS) data were collected using a phase sensitive multimeter (model PSM 1700, UK) in the frequency range $0.01 \mathrm{~Hz}-100 \mathrm{kHz}$ using a voltage bias of $5 \mathrm{mV}$.

\section{Results and discussion}

\subsection{Structural investigations}

The structural properties of layered $\mathrm{Li}_{1.2} \mathrm{Ni}_{0.13} \mathrm{Mn}_{0.54} \mathrm{Co}_{0.13} \mathrm{O}_{2}$ powders synthesized by sol-gel method were investigated by X-ray diffraction and Raman spectroscopy. Figure 1 displays the XRD patterns of the synthesized LLNMC samples. Except for the superlattice lines in the 20range $20-25^{\circ}$, the Bragg lines are well indexed to the layered $\alpha-\mathrm{NaFeO}_{2}$ structure with the $R \overline{3} m$ rhombohedral symmetry. No extra reflection peaks corresponding to any impurity phases were detected in XRD patterns indicating the high purity of as-prepared samples. The inserts in Figure 1 show the magnification of the low intensity lines in the $2 \theta$-range $20-25^{\circ}$ indexed to monoclinic $C 2 / m$ structure $[3,54,55]$. These features are not only related to the degree of Li-ion ordering in the transition-metal (TM) layer, but also to the particle size and the number of planar defects along the TM layers [56-58], which result in crystal rotation of the monoclinic $C 2 / m$ structure [59]. Based on the XRD results the synthesized materials can be viewed as a combination of two phases, the rhombohedral $R \overline{3} m$ phase $\left(\mathrm{LiNi}_{0.33} \mathrm{Mn}_{0.33} \mathrm{Co}_{0.33} \mathrm{O}_{2}\right)$ and the monoclinic $C 2 / m$ phase $\left(\mathrm{Li}_{2} \mathrm{MnO}_{3}\right)$. The materials can be formulated as $x \mathrm{Li}_{2} \mathrm{MnO}_{3} \bullet(1 x) \mathrm{LiNi}_{0.33} \mathrm{Mn}_{0.33} \mathrm{Co}_{0.33} \mathrm{O}_{2}$ with $x=0.5$.

Figure 2 presents the Rietveld refinements. For the $R \overline{3} m$ phase, refinement involved fixing the 
$\mathrm{Mn}$ and Co occupancy and varying the ratios of the Ni occupancies on the transition metal and lithium sites. The crystallographic parameters for the LLNMC samples are listed in Table 1. For all samples, the (006)/(102) and (108)/(110) doublets are sharp and split clearly, with higher $c_{\text {hex }} /$ $a_{\text {hex }}$ ratios (>4.98), indicating the good anisotropy of the layered frameworks [53]. The $I_{103} / I_{104}$ intensity ratio is currently considered as one of the indicators of the degree of cation mixing $[60,61]$. Higher value of $\mathrm{I}_{103} / \mathrm{I}_{104}$ is desirable for lower amount of the cation mixing and better electrochemical properties. It is also believed that the lower value of $\left(I_{006}+I_{102}\right) / I_{101}$ is an indicator of better hexagonal ordering $[8,62,63]$. The results reported in Table 1 show that the $I_{103} / I_{104}$ is high for all the samples; however, due to the uncertainty on the value of this parameter, it is not possible to make a clear distinction between the different samples. On another hand, the peak intensity ratio of $I_{103} / I_{104}$ increased significantly for the LLNMC synthesized samples in the sequence $\mathrm{SSG}<\mathrm{CA}-\mathrm{EDTA}<\mathrm{CA}<\mathrm{EDTA}$ making the $\mathrm{Li}_{1.2} \mathrm{Ni}_{0.13} \mathrm{Mn}_{0.54} \mathrm{Co}_{0.13} \mathrm{O}_{2}$ powders synthesized with assistance of EDTA chelator the best candidate for high electrochemical performances. Note that the cationic mixing (i.e. concentration of $\mathrm{Ni}^{2+}$ ions located in the $\mathrm{Li}^{+}$ sites) is lower than $2 \%$ for all samples and the phase ratio is close to the nominal fraction $(x=0.5)$. Table 1 also shows that the $\left[I_{(006)}+I_{(102)}\right] / I_{(101)}$ ratio is higher in the CA- and EDTAsamples, which suggests that the hexagonal ordering is smaller.

Table 1. The structural parameters of $\mathrm{Li}_{1.2} \mathrm{Ni}_{0.13} \mathrm{Mn}_{0.54} \mathrm{Co}_{0.13} \mathrm{O}_{2}$ powders prepared by sol-gel method via different chelators, and without chelator (SSG).

\begin{tabular}{lllll}
\hline Crystal data & \multicolumn{4}{c}{$\mathrm{Li}_{1.2} \mathrm{Ni}_{0.13} \mathrm{Co}_{0.13} \mathrm{Mn}_{0.54} \mathrm{O}_{2}$} \\
\cline { 2 - 5 } & $\mathrm{CA}$ & EDTA & CA-EDTA & SSG \\
\hline
\end{tabular}




\begin{tabular}{|c|c|c|c|c|}
\hline \multicolumn{5}{|l|}{ Lattice parameters } \\
\hline$a(\dot{A})$ & $2.849(6)$ & $2.849(2)$ & $2.848(9)$ & $2.848(9)$ \\
\hline$c(\AA)$ & $14.226(9)$ & $14.220(8)$ & $14.218(6)$ & $14.214(5)$ \\
\hline$c / a$ & $4.992(6)$ & 4.991(3) & $4.990(3)$ & $4.989(4)$ \\
\hline$I_{(003)} / I_{(104)}$ & 1.41 & 1.45 & 1.37 & 1.32 \\
\hline$\left[I_{(006)}+I_{(102)}\right] / I_{(101)}$ & 0.42 & 0.41 & 0.35 & 0.37 \\
\hline Coherent length $(L)(\mathrm{nm})$ & 121 & 136 & 148 & 172 \\
\hline Strain $* 10^{-4}$ & 6.04 & 4.53 & 2.95 & 2.75 \\
\hline \multicolumn{5}{|l|}{ Reliability Factors } \\
\hline$R_{p}(\%)$ & 20.0 & 21.4 & 22.9 & 22.3 \\
\hline$R_{w}(\%)$ & 21.8 & 22.2 & 25.9 & 26.3 \\
\hline$R_{\exp }$ & 21.3 & 21.23 & 23.8 & 23.5 \\
\hline$X^{2}$ & 1.05 & 1.09 & 1.22 & 1.15 \\
\hline $\mathrm{Ni}^{2+}$ (in Li layer of $R \overline{3} m$ ) & 0.0125 & 0.0129 & 0.0144 & 0.0157 \\
\hline \multicolumn{5}{|l|}{ Phase fraction } \\
\hline$R 3 m$ & 48.63 & 48.14 & 48.57 & 47.46 \\
\hline$C 2 / m$ & 51.37 & 51.86 & 51.43 & 52.54 \\
\hline $\operatorname{BET}\left(\mathrm{m}^{2} \mathrm{~g}^{-1}\right)$ & 4.6 & 9.0 & 5.4 & 2.4 \\
\hline
\end{tabular}

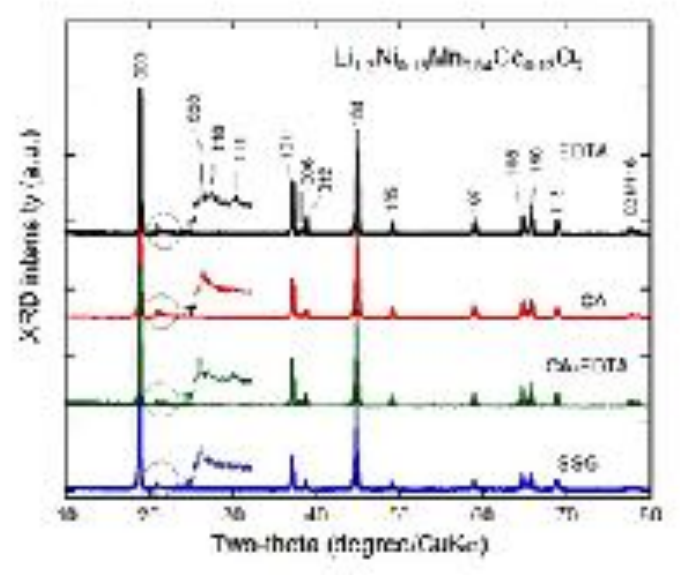

Figure 1. XRD pattern of $\mathrm{Li}_{1.2} \mathrm{Ni}_{0.13} \mathrm{Mn}_{0.54} \mathrm{Co}_{0.13} \mathrm{O}_{2}$ powders synthesized by sol-gel method assisted by different chelating agents and without chelating agent. Inserts show the detailed patterns in the $2 \theta$ range $20-25^{\circ}$ due to the monoclinic phase. 

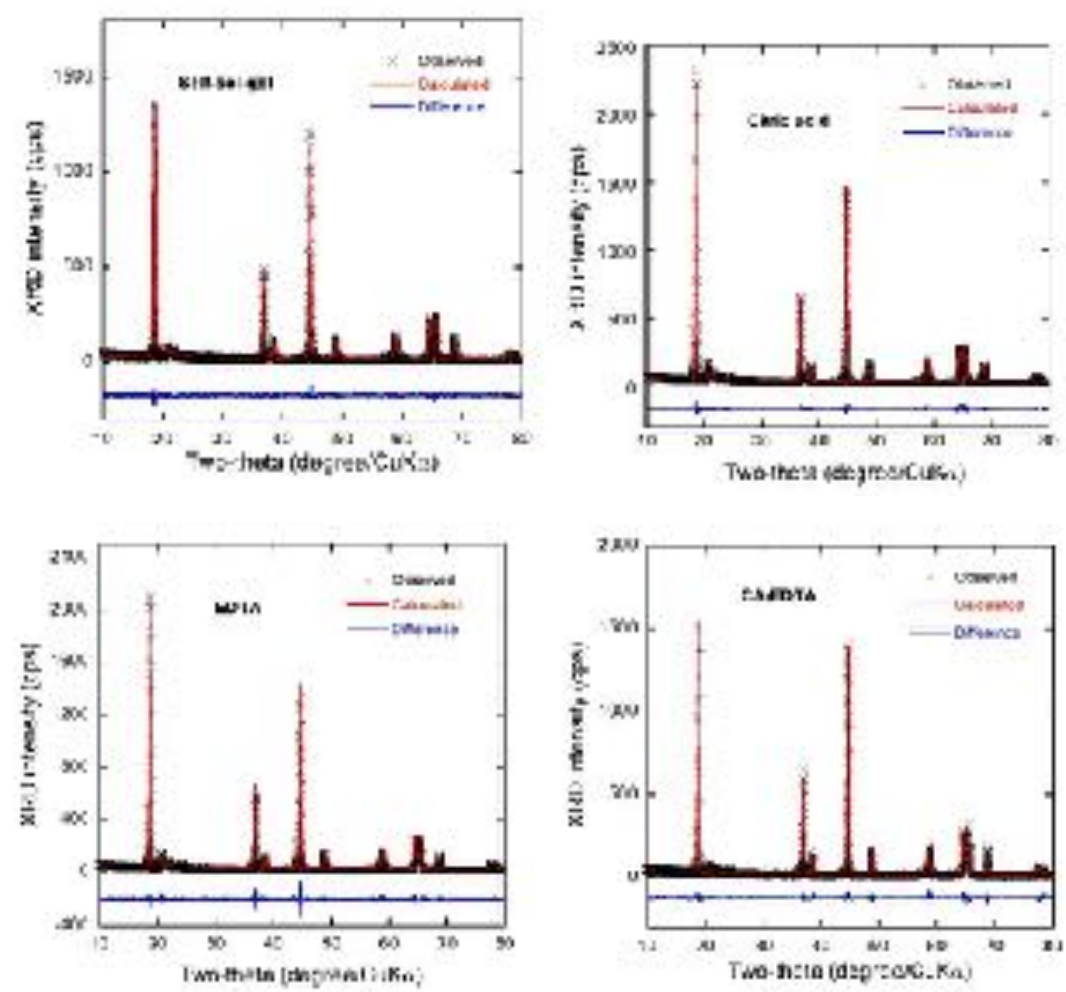

Figure 2. Rietveld refinements of powder XRD patterns for Li-rich $\mathrm{Li}_{1.2} \mathrm{Ni}_{0.13} \mathrm{Co}_{0.13} \mathrm{Mn}_{0.54} \mathrm{O}_{2}$ synthesized by wet chemistry using different chelating agents. Both monoclinic $\mathrm{Li}_{2} \mathrm{MnO}_{3}$ and rhombohedral $\mathrm{LiNi}_{1 / 3} \mathrm{Co}_{1 / 3} \mathrm{Mn}_{1 / 3} \mathrm{O}_{2}$ phases were considered.

To understand this effect, we note that the excess of alkali ions $\left(\mathrm{Li}^{+}\right)$in $\mathrm{TM}$ planes of $\mathrm{Li}_{1.2} \mathrm{Ni}_{0.13} \mathrm{Mn}_{0.54} \mathrm{Co}_{0.13} \mathrm{O}_{2}$ preferentially around $\mathrm{Mn}$ atoms, results in a bimodal distribution of local chemical environments, i.e. $\mathrm{Li}_{2} \mathrm{MnO}_{3}$ around $\mathrm{Mn}$ atoms and $\mathrm{Li}_{2} \mathrm{O}_{2}(M=\mathrm{Ni}, \mathrm{Mn}, \mathrm{Co})$, in the vicinity of TM cations. In addition, the coexistence of these phases with different bond lengths and lattice environments induces tensile strain in particles and increases the disorder parameters of the $\mathrm{Li}_{1.2} \mathrm{Ni}_{0.13} \mathrm{Mn}_{0.54} \mathrm{Co}_{0.13} \mathrm{O}_{2}$ samples [64]. Thus, the local strain caused by defects and lattice deformations depends on the crystallite nucleation, i.e. the synthesis conditions imposed by the chelating agent. The strain field intensity and the coherence length that sizes the structural disorder can be deduced from the Scherrer's formula: 


$$
B^{2} \cos ^{2} \theta=16<e^{2}>\sin ^{2} \theta+K^{2} \lambda^{2} / L^{2}
$$

where $B$ is the full-width at half-maximum (FWHM) in radian of the XRD spectrum at the Bragg angle $\theta, L$ is the coherence length (crystallite size) , $<e^{2>}$ is the lattice strain, $K$ is a near-unity constant related to crystallite shape (we have chosen the standard value $K=0.8$ ) and $\lambda$ is the wavelength of the $\mathrm{K}_{\alpha 1}$ radiation. The plot of the first member as a function of $\sin ^{2} \theta$ is reported in Fig. 3 for different chelating agents. The curves are linear for all the $\mathrm{Li}_{1.2} \mathrm{Ni}_{0.13} \mathrm{Mn}_{0.54} \mathrm{Co}_{0.13} \mathrm{O}_{2}$ materials, in agreement with Eq. (1). The crystallite size $(L)$ and the lattice strain $\left(e^{2}\right)$ were calculated from the intercept and the slope of the line, respectively. The resulting values are summarized in Table 1. As a result, the crystallite size decrease and the lattice strain increase, especially in the samples CA and EDTA. This result is consistent with the smaller value of the coherence length (size of the mono-crystallites) and the larger strain field observed in these two samples, and confirms that these samples contain crystal defects more than other two samples. This will be clarified in the next section.
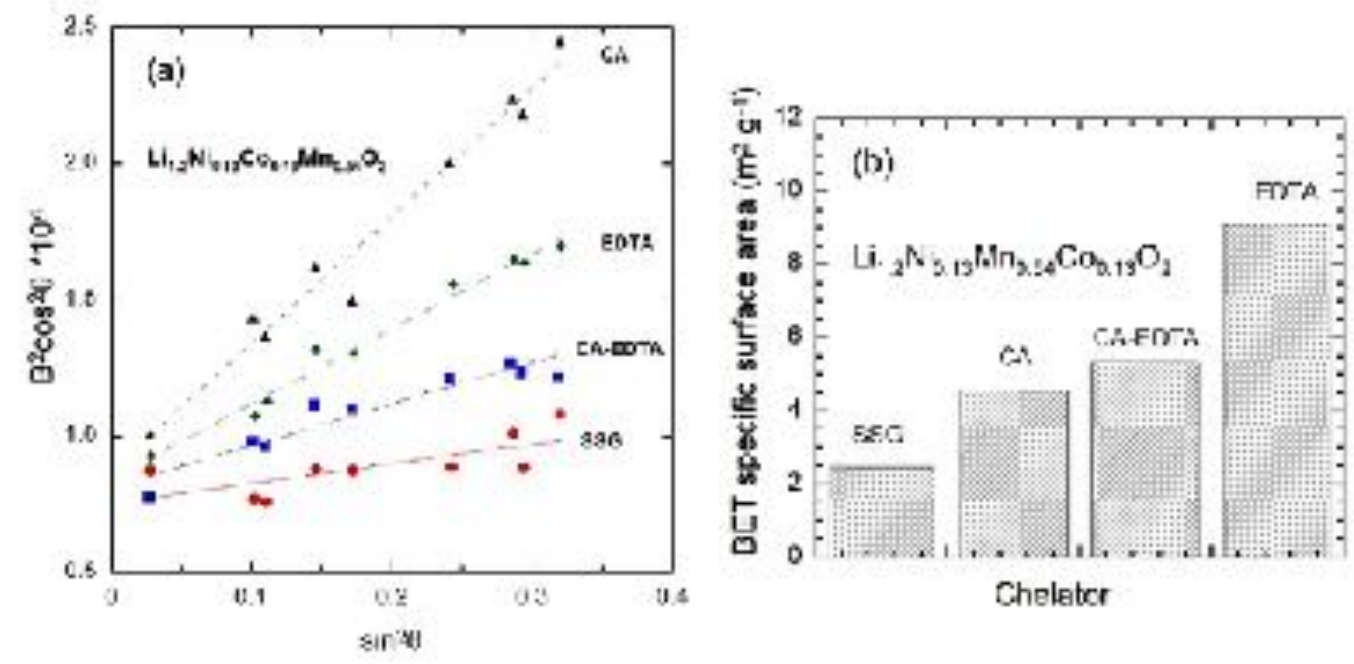

Figure 3. (a) Analysis of the micro-strain in $\mathrm{Li}_{1.2} \mathrm{Ni}_{0.13} \mathrm{Mn}_{0.54} \mathrm{Co}_{0.13} \mathrm{O}_{2}$ powders. $<e^{2>}$ was calculated using the Eq. (2). (b) BET surface area of $\mathrm{Li}_{1.2} \mathrm{Ni}_{0.13} \mathrm{Mn}_{0.54} \mathrm{Co}_{0.13} \mathrm{O}_{2}$ powders as a function of the chelating agent.

The porosity is another important parameter. To overcome a loss in specific capacity, porous cathodes are being extensively employed. A large porosity implies a large effective surface area 
with the electrolyte. This is favourable to the rate capability, but it can also accelerate the electrolyte decomposition, so that a compromise has to be found. The specific surface area of the $\mathrm{Li}_{1.2} \mathrm{Ni}_{0.13} \mathrm{Mn}_{0.54} \mathrm{Co}_{0.13} \mathrm{O}_{2}$ particles has been studied by BET measurements (Fig. $3 \mathrm{~b}$ and Table 1). these results show that the EDTA-prepared LLNMC powders exhibit a specific surface area of 9 $\mathrm{m}^{2} \mathrm{~g}^{-1}$, which is beneficial to the electrochemical performance.

The composition and the distribution of $3 d$-transition metals in the prepared samples were further examined by EDX spectroscopy. The results are reported in Figure 4. Li cannot be detected because of its low energy density. To identify the chemical composition of the prepared samples, the percentage of each TM cation is calculated by dividing its atomic percent by the summation of total atomic percent of all TM species. Table 2 lists the calculated compositions for the four samples before and after the synthesis. It can be found that the calculated percent value for the elements $\mathrm{Mn}, \mathrm{Ni}$, and $\mathrm{Co}$ are approximately the same as the theoretical values.

Table 2. Nominal and chemical composition measurements of $\mathrm{Li}_{1.2} \mathrm{Ni}_{0.13} \mathrm{Mn}_{0.54} \mathrm{Co}_{0.13} \mathrm{O}_{2}$ prepared by the different sol-gel routes.

\begin{tabular}{cccccc}
\hline Element & $\begin{array}{c}\text { Nominal (at. } \\
\%)\end{array}$ & \multicolumn{4}{c}{ Chemical composition (at.\%) } \\
\hline \\
\hline Mn K & 67.5 & SSG & CA & CA-EDTA & EDTA \\
Ni K & 16.25 & 67.7 & 67.2 & 67.0 & 67.1 \\
Co K & 16.25 & 15.7 & 16.3 & 16.3 & 16.5 \\
\hline
\end{tabular}



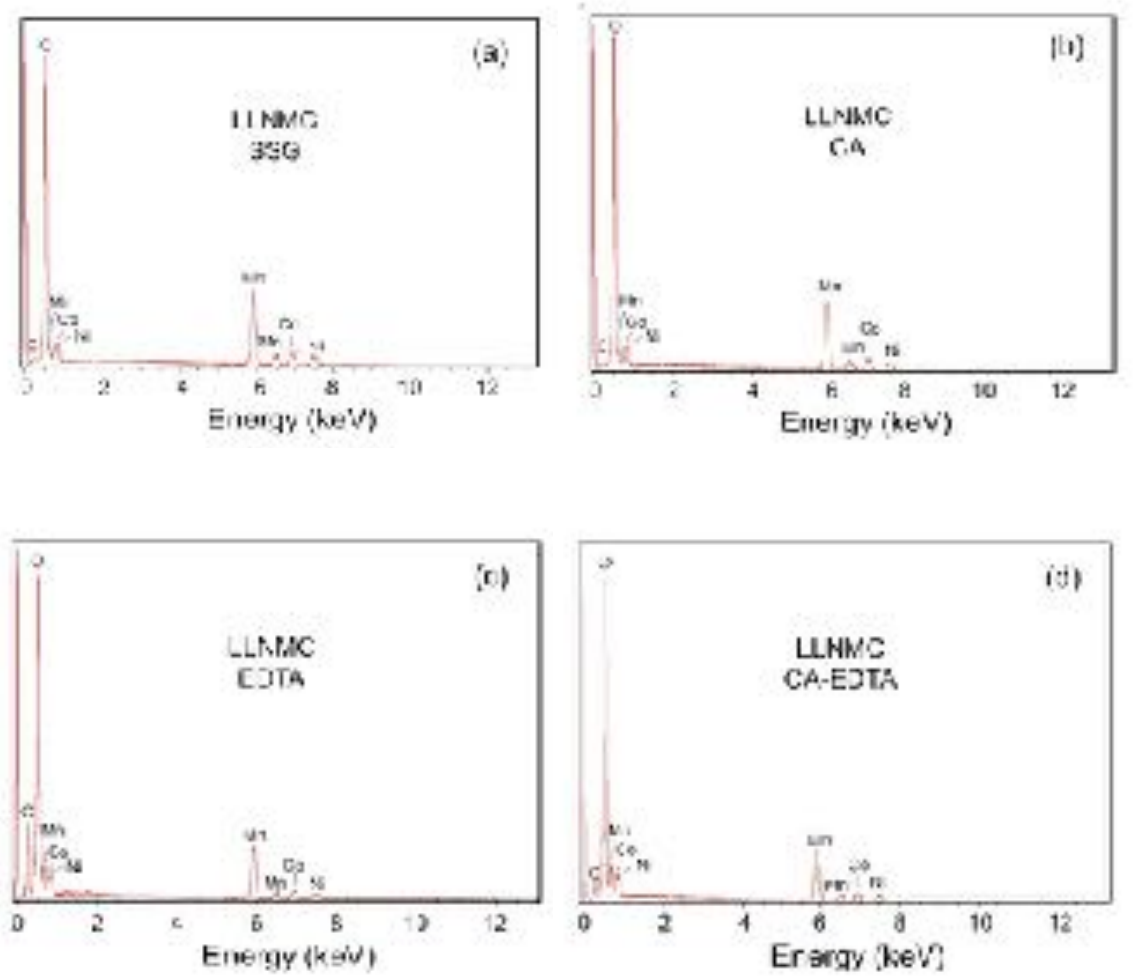

Figure 4. EDX analysis of $\mathrm{Li}_{1.2} \mathrm{Ni}_{0.13} \mathrm{Mn}_{0.54} \mathrm{Co}_{0.13} \mathrm{O}_{2}$ powders with and without chelating agent. EDX $\mathrm{L}_{\alpha}$ peaks are observed in the $0.6-0.85 \mathrm{keV}$ energy range while $\mathrm{K}_{\alpha}$ peaks are pointed out at $5.9-7.5 \mathrm{keV}$.

\subsection{Morphological characterization}

The electronic microscopy (SEM, TEM and HRTEM) analyses were carried out not only to clarify the effect of chelating agents on the crystal texture, but also to determine the particle size, morphology and degree of $\mathrm{Li}$ ordering $(\mathrm{C} 2 / \mathrm{m}$ phase) in the TM layers. The morphologies investigated by SEM are shown in Figs. 5a-d for $\mathrm{Li}_{1.2} \mathrm{Ni}_{0.13} \mathrm{Mn}_{0.54} \mathrm{Co}_{0.13} \mathrm{O}_{2}$ samples prepared by SSG, CA-EDTA, CA and EDTA, respectively. 


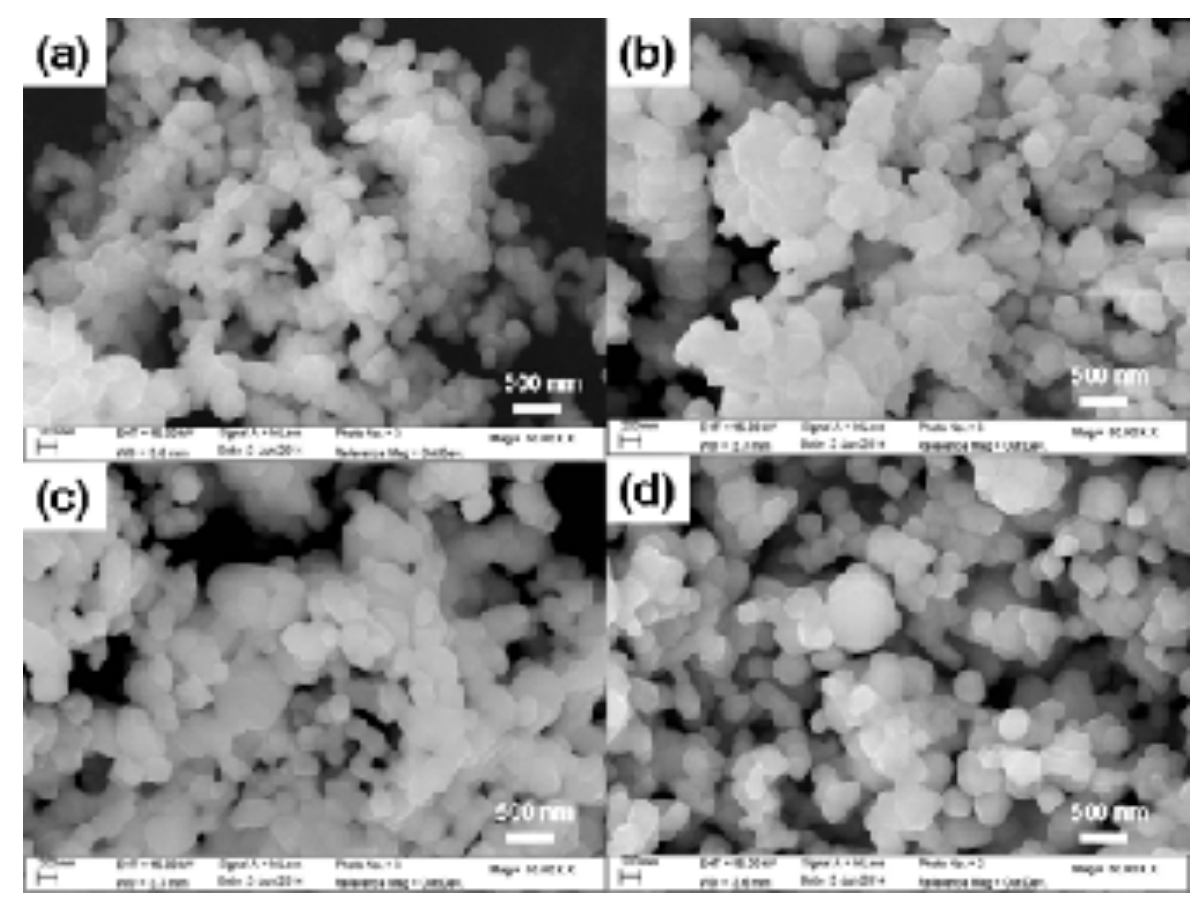

Figure 5. Scanning electron micrographs of $\mathrm{Li}_{1.2} \mathrm{Ni}_{0.13} \mathrm{Mn}_{0.54} \mathrm{Co}_{0.13} \mathrm{O}_{2}$ powders at magnifications of 10 and 50k×: (a and b) SG, (c and d) CA-EDTA, (e and f) CA and (g and h) EDTA.

Figure 6 shows the TEM images of the $\mathrm{Li}_{1.2} \mathrm{Ni}_{0.13} \mathrm{Mn}_{0.54} \mathrm{Co}_{0.13} \mathrm{O}_{2}$ powders prepared by SSG, CA-EDTA, CA and EDTA, respectively. As evidenced, the $\mathrm{Li}_{1.2} \mathrm{Ni}_{0.13} \mathrm{Co}_{0.13} \mathrm{Mn}_{0.54} \mathrm{O}_{2}$ powders appear as homogeneous sphere-like particles with a uniform size distribution in the range 150$200 \mathrm{~nm}$. The corresponding HRTEM images (Fig. 6 b, d, f and h) exhibit clearly lattice fringes with a $d$-spacing of $\approx 0.47 \mathrm{~nm}$, which matches well with the inter-planar distance of the $(003)_{\text {hex }}$ of $\mathrm{Li}_{2} \mathrm{O}_{2}$ and/or the $(001)_{\text {mon }}$ of $\mathrm{Li}_{2} \mathrm{MnO}_{3}$ with a remarkable structural compatibility [65]. Therefore, it is more difficult to differentiate between the two layered structures. Based on these observations, all samples exhibit obviously well-defined fringes indicating the good crystallinity of powders. The particle size is about the same in all the samples. It is well known that the size, morphology and the distribution of the particles are of great importance for Li-ion battery performance. Generally, lithium insertion/extraction is much easier with active materials having small particle size to limit the length that the $\mathrm{Li}^{+}$ions must cross to arrive at the surface. However, no significant difference of morphology and size distribution of the particles can be 
detected between the four samples, so that any difference in the electrochemical properties will not be attributable to such parameters.
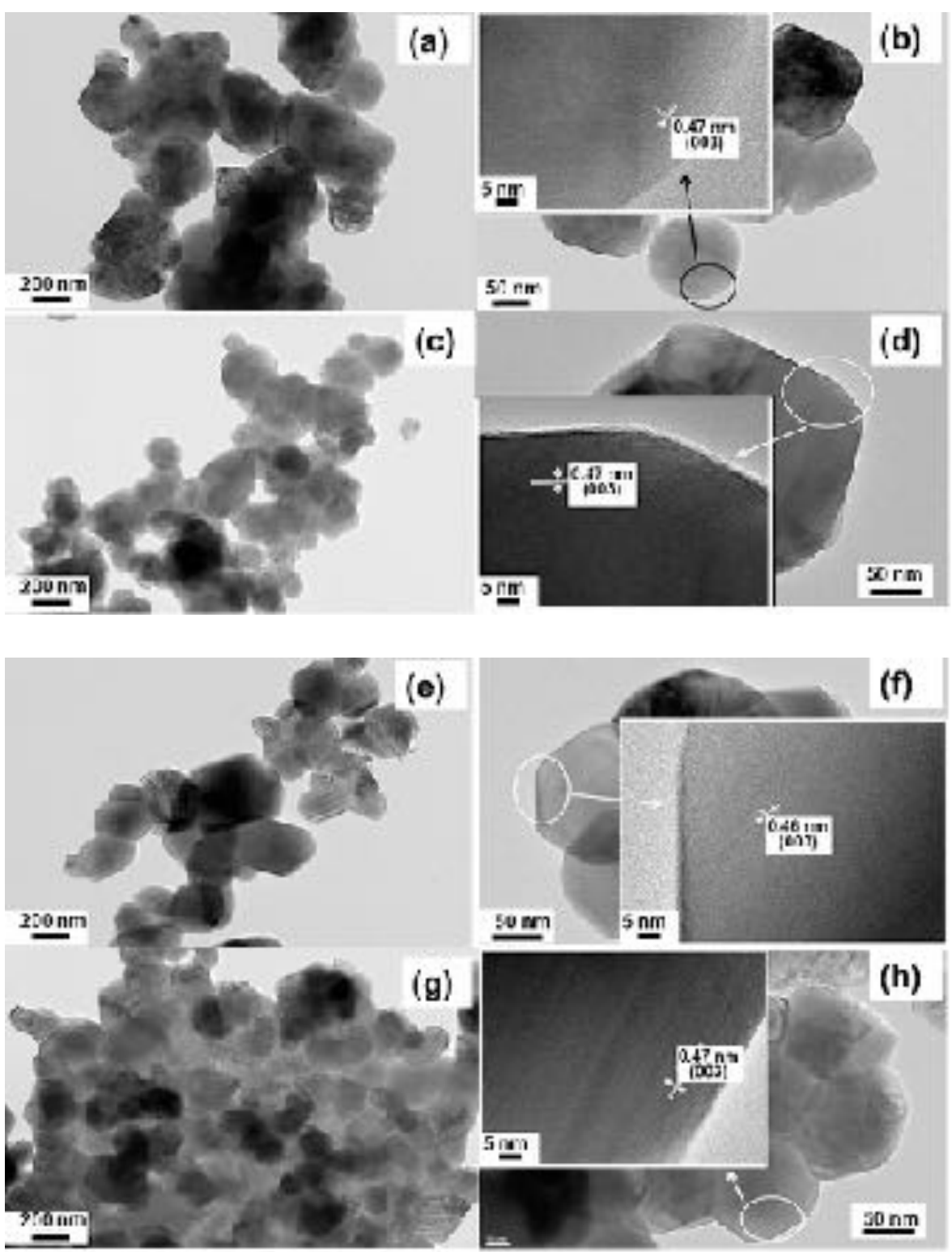

Figure 6. TEM and HRTEM of $\mathrm{Li}_{1.2} \mathrm{Ni}_{0.13} \mathrm{Mn}_{0.54} \mathrm{Co}_{0.13} \mathrm{O}_{2}$ powders synthesized by sol-gel route: SSG (a and b), CA-EDTA (c and d), CA (e and f), and EDTA (g and h). The well-resolved lattice fringes indicate the crystallinity of the sample.

The selected area electron diffraction (SAED) patterns of the $\mathrm{Li}_{1.2} \mathrm{Ni}_{0.13} \mathrm{Mn}_{0.54} \mathrm{Co}_{0.13} \mathrm{O}_{2}$ powders are shown in Fig. 7 a-d. The SAED pattern consists mainly of two types of reflections; 
(i) strong reflections that can be treated as fundamental reflections (marked as solid arrow), (ii) weak triplet reflections that appear in between two fundamental reflections (marked as dotted arrow) [66]. Reflections of the first type (fundamental reflections) are from rhombohedral $(R \overline{3} m)$ phase and often designated as O3 reflections (Fig.7 a-d). These reflections appear due to random distribution of the cations in the TM layer without any long-range ordering. Therefore, ordering between lithium and transition metal ions in the transition metal layers is not present. The weak triplet reflections observed in Fig. 7 suggest the presence of the monoclinic $(C 2 / m)$ phase. These reflections illustrate the ordering of lithium ions with the cations in the TM layers. The presence of lithium ions in the transition metal layer creates a long-range ordering in the unit cell. Note these two types of reflection are observed in all four samples (Fig.7 a-d).

In addition to the two types of reflections mentioned above, forbidden reflections (1010) only appear in the CA and EDTA samples (Fig.7c and d). These reflections are normally observed in a trigonal/rhombohedral symmetry along the (0001) zone direction. The presence of such reflections indicate that the rhombohedral symmetry is disturbed in these two samples, with stacking faults or dislocations in the unit cell [66-68]. This result is also consistent with the higher local strain-field detected by XRD in the CA and EDTA samples. 

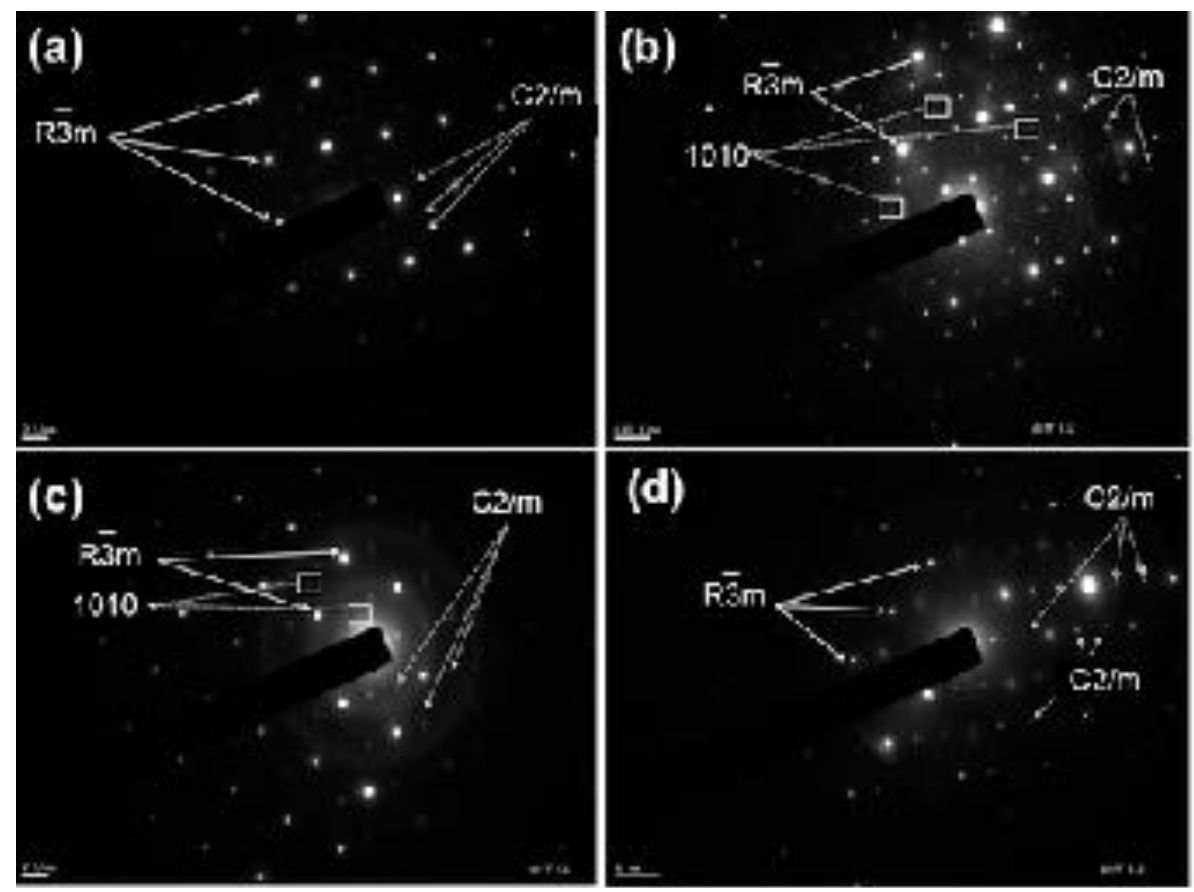

Figure 7. SAED patterns of $\mathrm{Li}_{1.2} \mathrm{Ni}_{0.13} \mathrm{Mn}_{0.54} \mathrm{Co}_{0.13} \mathrm{O}_{2}$ powders synthesized with and without chelating agents assisted sol-gel method, (a) SSG, (b) CA-EDTA, (c) CA and (d) EDTA.

\subsection{Vibrational properties}

X-ray diffraction analysis can be used to determine the order of the crystal structure at the long-range scale. Raman scattering was used as a complimentary tool because it is not only sensitive to the short-range order of the lattice $[60,70]$. Figure 8 shows the Raman scattering spectra of $\mathrm{Li}_{1.2} \mathrm{Ni}_{0.13} \mathrm{Mn}_{0.54} \mathrm{Co}_{0.13} \mathrm{O}_{2}$ samples synthesized by the different methods. All the samples display the same Raman fingerprints, in which the four Raman active modes of $\mathrm{Li}_{1.2} \mathrm{Ni}_{0.13} \mathrm{Co}_{0.13} \mathrm{Mn}_{0.54} \mathrm{O}_{2}$ are observed at ca. $661,603,491$, and $435 \mathrm{~cm}^{-1}$. This result is in good agreement with those reported in the literature [70-73] and is consistent with the factor group analysis of the $R \overline{3} m$ and $C 2 / m$ symmetry, respectively. In general, there are two predicted Raman-active vibrational modes $\mathrm{A}_{1 \mathrm{~g}}$ and $\mathrm{E}_{\mathrm{g}}$ in the ideal layered oxide $\left(\mathrm{Li} M \mathrm{O}_{2}\right)$ with $\mathrm{R} 3 \mathrm{~m}$ symmetry. The $A_{1 \mathrm{~g}}$ and $E_{\mathrm{g}}$ originated from the stretching $M-\mathrm{O}$ and bending $\mathrm{O}-M-\mathrm{O}$ vibrations, respectively [8,74], which corresponds to two sharp Raman peaks near 603 and $491 \mathrm{~cm}^{-1}$, respectively. The $\mathrm{A}_{\lg }$ mode has the greater oscillator strength and that the intensity is almost twice that of the $E_{\mathrm{g}}$ mode [69]. An additional small Raman band at $435 \mathrm{~cm}^{-1}$ originates from the 
$\mathrm{Li}_{2} \mathrm{MnO}_{3}$-like structure due to the reduced local symmetry of $C 2 / m$ rather than $R \overline{3} m[73]$. The high-frequency band at $661 \mathrm{~cm}^{-1}$ is characteristic of the spinel phase $[75,76]$ and is observed in all our samples. Therefore, according to our synthesis process, a small part of the particle surface is in the spinel structure. Note, however, that the intensity of this Raman band is smaller than in the case of Li-rich samples synthesized under synthesis conditions allowing the transformation of the pristine layered structure to a spinel structure for facilitating Li-ion transport in the surface area [77].

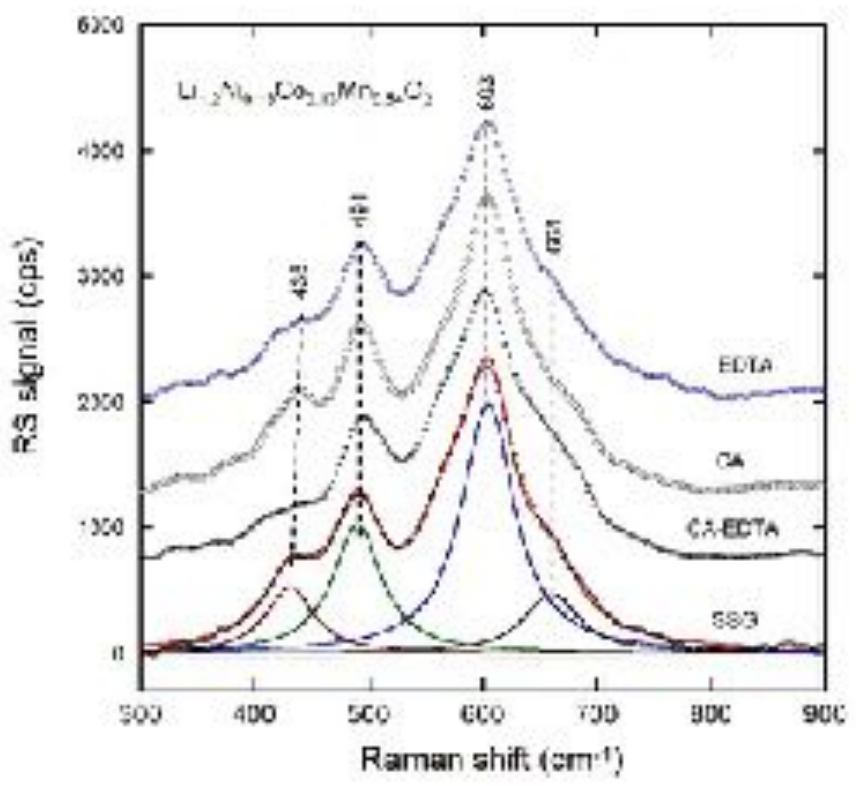

Figure 8. Raman scattering spectra of $\mathrm{Li}_{1.2} \mathrm{Ni}_{0.13} \mathrm{Mn}_{0.54} \mathrm{Co}_{0.13} \mathrm{O}_{2}$ powders synthesized with and without chelating agents. The spectral analysis using Lorentzian line profiles are plotted for evaporation sample.

\subsection{Electrochemical properties}

Figure 9 (a-d) shows the charge/discharge profiles of as-prepared $\mathrm{Li}_{1.2} \mathrm{Ni}_{0.13} \mathrm{Mn}_{0.54} \mathrm{Co}_{0.13} \mathrm{O}_{2}$ electrodes cycled at $0.1 \mathrm{C}$ rate in the potential between 2.0 and $4.8 \mathrm{~V}$ vs. $\mathrm{Li}^{+} / \mathrm{Li}$. All the initial charge/discharge profiles show the same general features as in previous works [78]. Below 4.5V, the sloping curve of the first charge corresponds to the de-intercalation of lithium ions from the layered structure $\left(\mathrm{LiNi}_{1 / 3} \mathrm{Co}_{1 / 3} \mathrm{Mn}_{1 / 3} \mathrm{O}_{2}\right)$ accompanied by the oxidation of $\mathrm{Ni}^{2+/ 4+}$ and $\mathrm{Co}^{3+/ 4+}$ [79]. 
The plateau at $4.5 \mathrm{~V}$ is the activation of the $\mathrm{Li}_{2} \mathrm{MnO}_{3}$ part, causing an irreversible oxygen evolution from the lattice in the form of $\mathrm{Li}_{2} \mathrm{O}$ and active $\mathrm{MnO}_{2}$ [80-82].
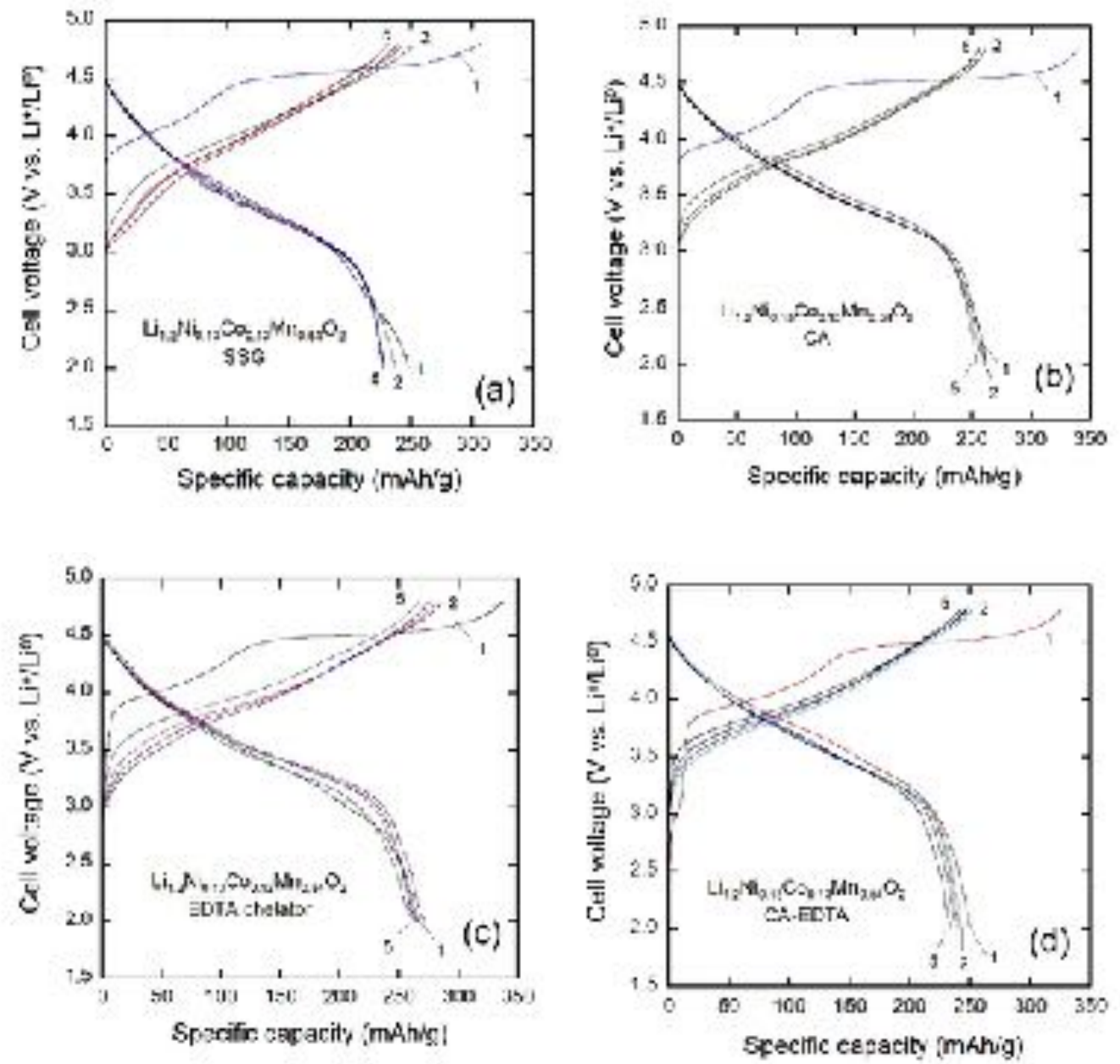

Figure 9. Galvanostatic charge/discharge profiles of $\mathrm{Li}_{1.2} \mathrm{Ni}_{0.13} \mathrm{Mn}_{0.54} \mathrm{Co}_{0.13} \mathrm{O}_{2}$ electrodes cycled at $0.1 \mathrm{C}$ rate in the potential between 2.0 and $4.8 \mathrm{~V}$ vs. $\mathrm{Li}^{+} / \mathrm{Li}$ (a) SSG (b) CA-EDTA, (c) CA, and (d) EDTA.

Figure 10 shows the incremental capacity curves (IC), i.e. differential capacity vs. cell voltage $(\mathrm{d} Q / \mathrm{d} V)$, at the $1^{\text {st }}$ and $50^{\text {th }}$ discharge. This analysis can be considered as an efficient tool to determine the electrochemical spectroscopy of an electrode. The IC curves were extracted from the GCD profiles (lithiation process) to further characterize the electrochemical behavior at the $50^{\text {th }}$ cycle. Each plot displays two broad peaks, one at $\sim 3.3 \mathrm{~V}$ commonly reflects $\mathrm{Mn}^{3+/ 4+}$ activities from the layered compound, and the other one at $\sim 3.7 \mathrm{~V}$ associated to the reduction of 
$\mathrm{Ni}^{2+/ 4+}[83,84]$. Figure 10 also shows that the EDTA electrode exhibits the highest potential at $3.39 \mathrm{~V}$ for the first plateau, while the second plateau at $3.74 \mathrm{~V}$ occurs for the CA-EDTA electrode. The voltage-fade issue of Li-rich cathode materials is an intrinsic weakness [85-87]. In addition, a small redox peak around $2.6 \mathrm{~V}$ confirms the presence of spinel structure with electrochemical activity in the EDTA-sample [23]. The origin of voltage decay is believed to be an intrinsic property due to the transition-metal ions migration, which induces layered-to-spinel transformation [88-90]. The good electrochemical features in Fig. 10 are attributable to the regular texture of the particle shown previously by TEM studies.
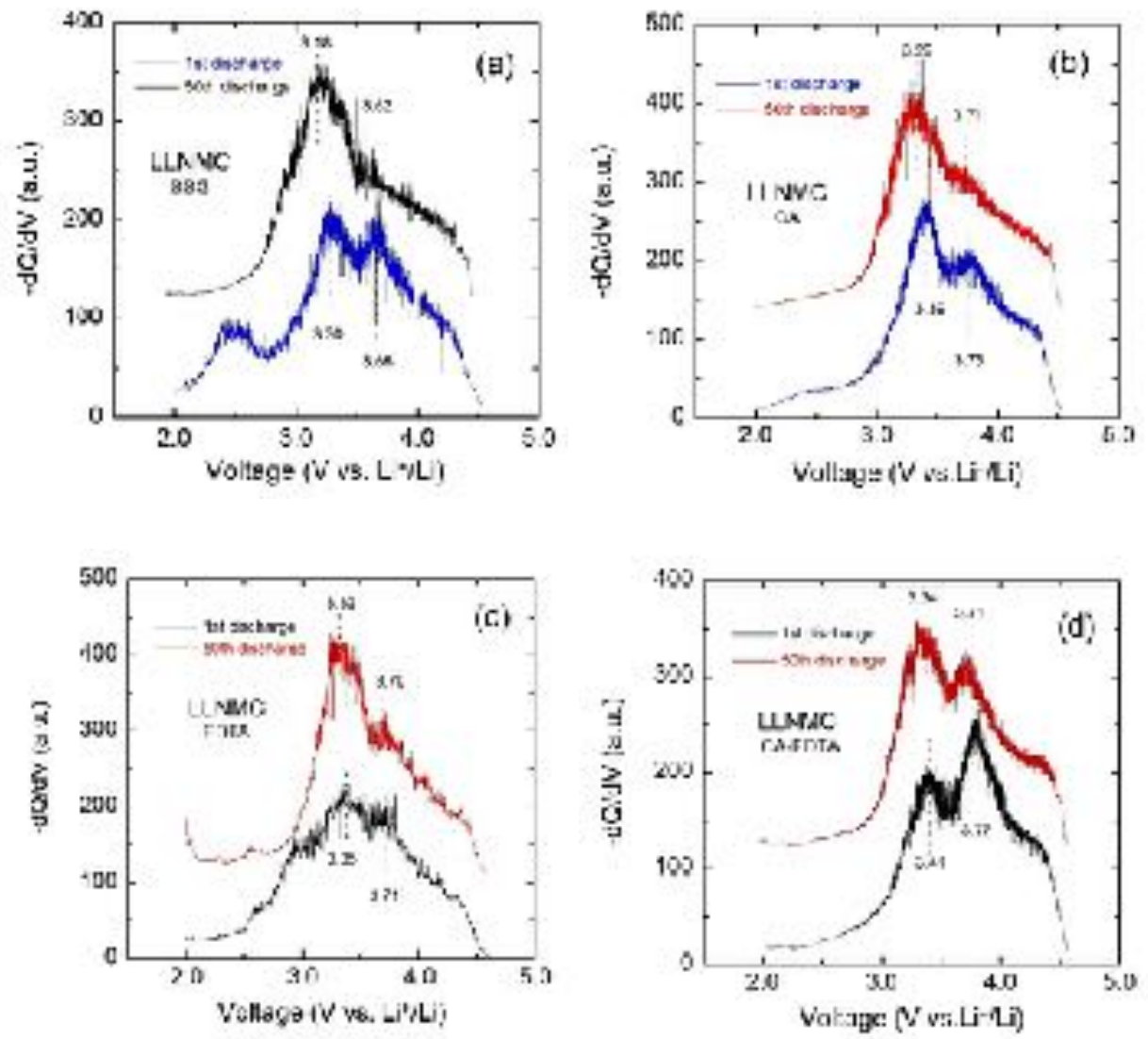

Figure 10. Differential voltage $\mathrm{d} Q / \mathrm{d} V$ vs. cell voltage for $\mathrm{Li}_{1.2} \mathrm{Ni}_{0.13} \mathrm{Mn}_{0.54} \mathrm{Co}_{0.13} \mathrm{O}_{2}$ electrodes taken at the $1^{\text {st }}$ and $50^{\text {th }}$ discharge. Cells were cycled at $0.1 \mathrm{C}$ rate. Curves are derived from data in Fig. 9.

As shown in the charge/discharge curves at 0.1C (Fig. 9), the EDTA and CA electrodes have not only a significantly higher initial discharge capacity of 267 and $262 \mathrm{mAh} \mathrm{g}^{-1}$, 
respectively, compared with those of the CA/EDTA (249 $\left.\mathrm{mAh} \mathrm{g}^{-1}\right)$ and SSG (228 $\left.\mathrm{mAh} \mathrm{g}^{-1}\right)$ electrodes, but also lower irreversible capacity-loss (ICL) in the range 75-78 $\mathrm{mAh} \mathrm{g}^{-1}$. For the synthesized materials, ICLs are in the sequence EDTA $<$ CA $<$ CA-EDTA $<$ SSG. The initial coulombic efficiencies appeared in the following order: EDTA $(79.1 \%)>$ CA $(77.8 \%)>$ CAEDTA $(76.5 \%)>\operatorname{SSG}(74.3 \%)$. Among the four materials, the EDTA and CA-materials present the lowest initial ICL, and the highest first charge/discharge capacity and initial coulombic efficiency.

To evaluate the rate capabilities of the synthesized $\mathrm{Li}_{1.2} \mathrm{Ni}_{0.13} \mathrm{Mn}_{0.54} \mathrm{Co}_{0.13} \mathrm{O}_{2}$ electrodes $(\mathrm{CA}$, EDTA, CA-EDTA and SSG), the cells were cycled in the volte range 2.0-4.8 V at various current rates from $0.1 \mathrm{C}$ to $3.0 \mathrm{C}\left(1 \mathrm{C}=250 \mathrm{~mA} \mathrm{~g}^{-1}\right)$ and the results are shown in Fig. 11a. Among the four electrodes under investigations, EDTA and CA-electrodes exhibited the best results at any rate. At 3.0C, these two electrodes demonstrated a discharge capacity 136 and $123 \mathrm{mAh} \mathrm{g}^{-1}$, respectively. Going back to $\mathrm{C} / 10$ after 30 cycles, EDTA and CA electrodes can retain discharge capacities of 245 and $238 \mathrm{mAh} \mathrm{g}^{-1}$, which represent 91.7 and $91 \%$ of the initial discharge capacity obtained at $\mathrm{C} / 10$ rate, which proves that the electrode material has not been damaged by cycling up to $3 \mathrm{C}$ rate.

The cycling performance of the $\mathrm{Li}_{1.2} \mathrm{Ni}_{0.13} \mathrm{Mn}_{0.54} \mathrm{Co}_{0.13} \mathrm{O}_{2} / /$ Li cells were carried out at $0.1 \mathrm{C}$ rate in the voltage range of 2.0-4.8 V (see Fig. 11b). Over 100 cycles, all the electrodes possess the same behavior for the cycling performance. The discharge capacity gradually decreases to different degrees during the initial fifteen cycles; which is followed by relative stability until the 50th cycle. After 50 cycle, the SSG electrode has the lower capacity retention $(75.4 \%)$. The retained discharge capacities after 50 cycles in the $2.0-4.8 \mathrm{~V}$ follow the trend: EDTA (227.5 mAh $\left.g^{-1}\right)>$ CA $\left(218.6\right.$ mAh g-1 $\left.^{-1}\right)>$ CA-EDTA $(206.5$ mAh g-1) $>$ SSG (187.3 mAh g-1) which represent capacity retentions $\%$ as in the same sequence also 85.6, 83.5, 82.1 and $75.4 \%$, respectively. For the best (EDTA) electrode, the capacities at the $20^{\text {th }}$ cycle and the $100^{\text {th }}$ cycle are 235 and $195 \mathrm{mAh} \mathrm{g}^{-1}$, corresponding to a capacity retention of $80 \%$. 

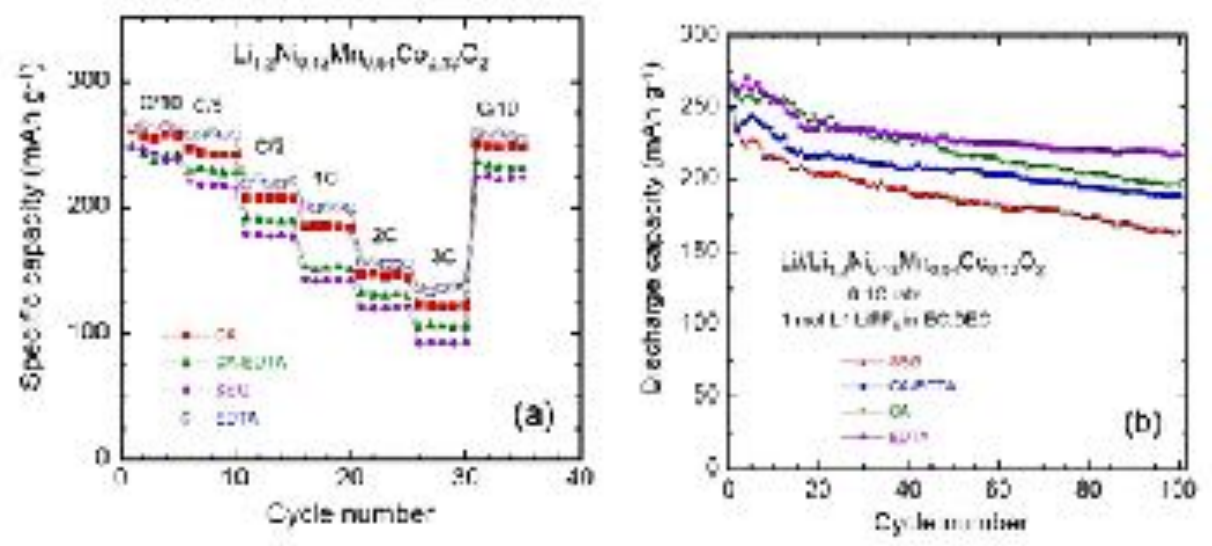

Figure 11. (a) Rate capability of $\mathrm{Li}_{1.2} \mathrm{Ni}_{0.13} \mathrm{Mn}_{0.54} \mathrm{Co}_{0.13} \mathrm{O}_{2}$ electrodes at different C-rates. (b) Cycling performance of $\mathrm{Li}_{1.2} \mathrm{Ni}_{0.13} \mathrm{Mn}_{0.54} \mathrm{Co}_{0.13} \mathrm{O}_{2}$ powders synthesized by sol-gel method assisted by different carboxylic acids. Experimental were carried out at $0.1 \mathrm{C}$ discharge rate in the potential between 2.0 and $4.8 \mathrm{~V}$.

Electrochemical impedance spectra (EIS) were carried out to explore the origin of the different electrochemical performance of the $\mathrm{Li}_{1.2} \mathrm{Ni}_{0.13} \mathrm{Mn}_{0.54} \mathrm{Co}_{0.13} \mathrm{O}_{2}$ powders. Figure $12(\mathrm{a}, \mathrm{b})$ shows the Nyquist plots of the fresh cell and after 5 cycles for the four $\mathrm{Li}_{1.2} \mathrm{Ni}_{0.13} \mathrm{Mn}_{0.54} \mathrm{Co}_{0.13} \mathrm{O}_{2}$ electrodes. EIS spectra were fitted using the equivalent circuit shown in Fig. 12c. Before cycling, at high frequency, all the EIS curves exhibit one depressed semicircle the diameter of which represents the interfacial charge transfer resistance between the surface film and the active cathode mass $\left(R_{\mathrm{ct}}\right)$. At low frequency, the linear region represents the Warburg contribution, related to the lithium ion diffusion in the bulk materials. The $R_{\mathrm{ct}}$ values of EDTA, CA, CA-EDTA and SSG of the fresh electrodes is $126,145,168$ and $233 \Omega$, respectively. After $5^{\text {th }}$ cycle at $0.1 \mathrm{C}$ (Fig. $12 \mathrm{~b}$ ), the $R_{\mathrm{ct}}$ values of EDTA and CA did not change significantly, while they have increased for CA-EDTA (265 $\Omega$ ) and SSG (388 $\Omega$ ) electrodes. In addition, the overall shape of the EIS spectra (deformed arc of cycle followed by a sloping part) is still conserved for the EDTA and CA electrodes. To the contrary, the shape of the EIS spectra of the CA-EDTA and SSG electrodes has been modified by the 5 cycles, with a highly resistive CPE component masking the sloping part that was observed before cycling. This gives evidence of the formation 
a highly resistive solid-electrolyte interface (SEI) due to side reactions between the electrolyte and the CA-EDTA and SSG-Li ${ }_{1.2} \mathrm{Ni}_{0.13} \mathrm{Mn}_{0.54} \mathrm{Co}_{0.13} \mathrm{O}_{2}$ particles. The lower value of $R_{\mathrm{ct}}$ for EDTA and CA electrodes also explains their higher rate capability.
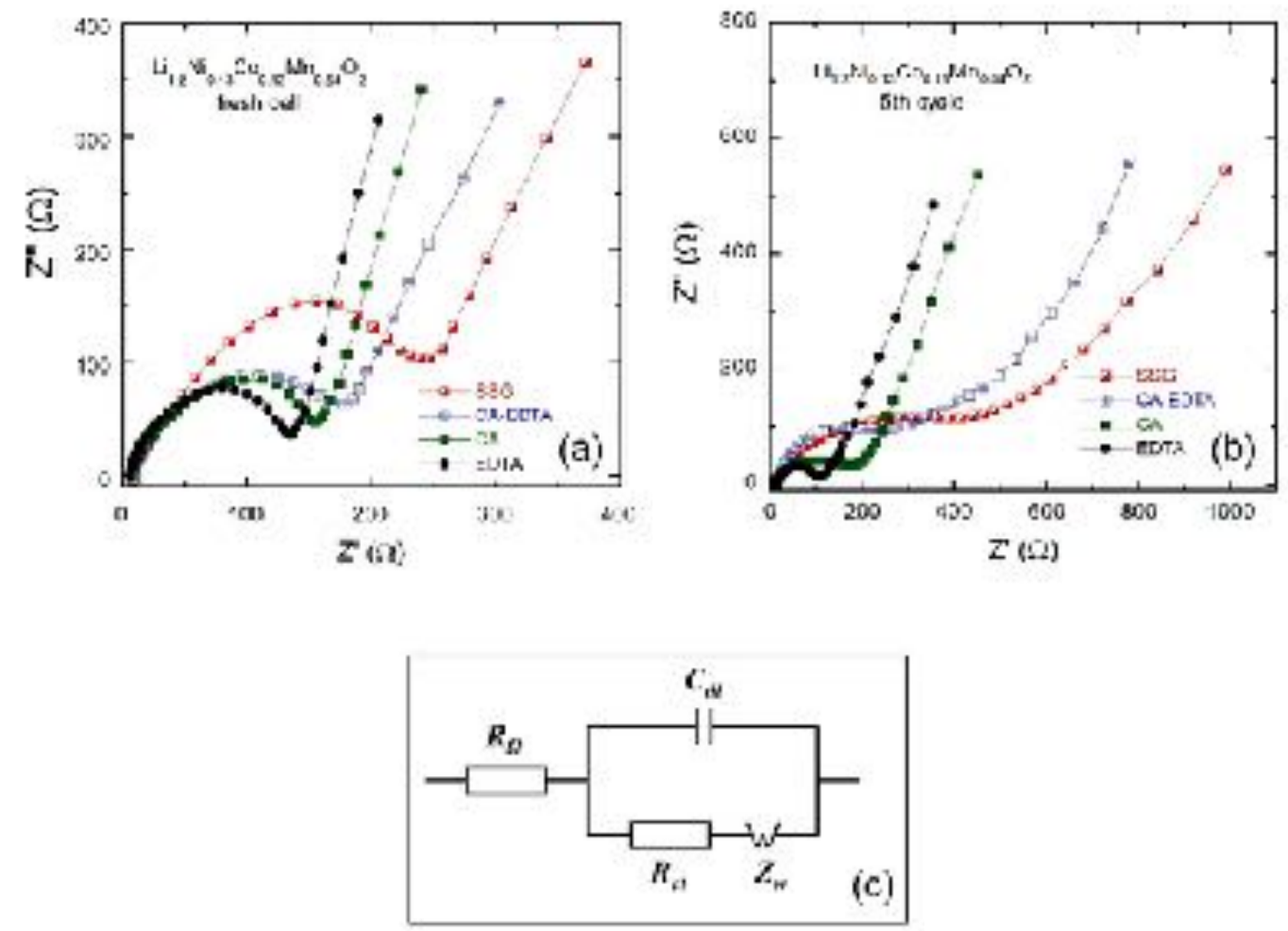

Figure 12. Electrochemical impedance spectra of $\mathrm{Li}_{1.2} \mathrm{Ni}_{0.13} \mathrm{Mn}_{0.54} \mathrm{Co}_{0.13} \mathrm{O}_{2}$ electrode in (a) fresh cell and (b) after and after 5 cycles. (c) Equivalent circuit used for the fit of Nyquist diagrams.

\section{Discussion}

A comparison of the results from electrochemical experiments shown in Fig. 13 evidences that materials prepared with EDTA and CA chelators exhibit the best performance in terms of discharge capacity and coulombic efficiency as well. The EIS experiments show that both the EDTA and CA chelating agents are effective to protect the surface of the $\mathrm{Li}_{1.2} \mathrm{Ni}_{0.13} \mathrm{Mn}_{0.54} \mathrm{Co}_{0.13} \mathrm{O}_{2}$ particles against reactions with the electrolyte forming a resistive SEI. This is caused by the formation of a protective spinel-like structure on the cathode surface, as the chelating agents remove some of the $\mathrm{Li}_{2} \mathrm{O}$ in the $\mathrm{Li}_{2} \mathrm{MnO}_{3}$ phase. In addition, a channel for $\mathrm{Li}^{+}$ transmission is created by this surface layer, and the impedance at the interface between the cathode 
material and the electrolyte is effectively reduced, facilitating the rapid transport of $\mathrm{Li}+$ through the electrode interface, which increases the rate capacity [31].
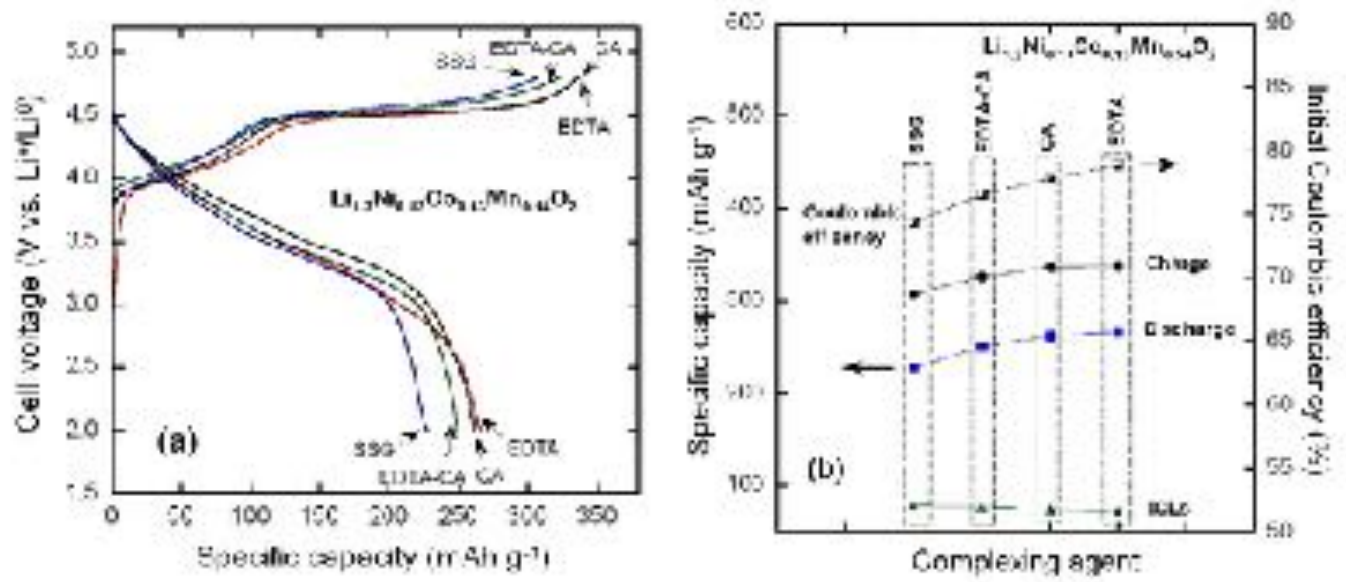

Figure 13. Electrochemical performance of the $\mathrm{Li}_{1.2} \mathrm{Ni}_{0.13} \mathrm{Mn}_{0.54} \mathrm{Co}_{0.13} \mathrm{O}_{2}$ electrodes. (a) charge/ discharge capacity. (b) Comparison of the charge, discharge capacity and coulombic efficiency as a function of the chelators.

The results also show that EDTA is a better reagent than CA, which reveals the insufficiency of citric acid to chelate all metal ions. A more surprising result is the poor result obtained with a combination CA-EDTA. For instance, this combination was found more efficient than EDTA alone to synthesize cerate-zirconate powders by a modified sol-gel method [91]. The combined CA-EDTA method was also found particularly useful for synthesizing ultra-fine powders of complex oxide compositions [92]. In our case, however, this combination was found inefficient. The main reason is that this combination failed to reduce the $\mathrm{Ni}^{2+}-\mathrm{Li}$ antisite defect, known to be responsible for a degradation of electrochemical properties in $\mathrm{LiNi}_{1 / 3} \mathrm{Mn}_{1 / 3} \mathrm{Co}_{1 / 3} \mathrm{O}_{2}$ [93]. After Table 1, the concentration of antisite defects remains at the level of $1.44 \%$, only slightly smaller than the concentration $(1.55 \%)$ found in the sample prepared without any chelating agent. To the contrary, the complexing ability of either CA or EDTA is very good, as it reduces the concentration of cation antisite defects to $1.27 \pm 0.02 \%$. In a previous study on the effect of chelating agents, Li et al. [31] have determined that CA was a less efficient chelating agent than sucrose or glucose, because one mole sucrose can be hydrolyzed into two different monosaccharides and further chelates three $\mathrm{M}(\mathrm{Li}, \mathrm{Ni}, \mathrm{Co}$ and $\mathrm{Mn}$ ) ions to form a more uniform ion-chelated matrix during sol-gel process. If we consider that CA is not a good candidate, we 
can attribute the failure of CA-EDTA to the fact that the amount of EDTA was too small in this mixture. On another hand, EDTA alone was efficient to fill the purpose in the present work. We can also note that the electrochemical properties of the sample prepared with EDTA is slightly degraded with respect to the results obtained in ref. [31] with sucrose as the chelating agent. However, we know that the concentration of antisite reduced to $1.25 \%$ in the EDTA-sample is small enough so that it does not affect the electrochemical properties [91]. Therefore, we believe that the difference between the electrochemical properties of the samples prepared with EDTA in this work and sucrose in [31] is not related to the amount of antisite defects. Instead, this difference is attributable to the different morphology of the particles and of the surface layer originating from other parameters of the synthesis, such as the $\mathrm{pH}$ of the solution (5 in [31] against 7-8 in the present case). Comparing with the electrochemical properties obtained with samples synthesized with the same $\mathrm{pH}$ and tested at $1 \mathrm{C}$ rate, we find that the capacity (202 $\mathrm{mAh}$ $\left.\mathrm{g}^{-1}\right)$ of the EDTA-sample is larger than the values reported in [25].

\section{Conclusions}

Four samples of $\mathrm{Li}_{1.2} \mathrm{Ni}_{0.13} \mathrm{Mn}_{0.54} \mathrm{Co}_{0.13} \mathrm{O}_{2}$ were prepared by a sol-gel method from an aqueous solution of Li, Ni, Mn and Co acetates, with different chelating agents: Citric acid (CA), ethylene diamine tetra-acetic acid (EDTA), a CA-EDTA mixture and free chelating agent (SSG). Characterization by XRD showed that all the samples are well crystallized with layered $\alpha$ $\mathrm{NaFeO}_{2}$ structure with a rhombohedral $R \overline{3} m$ space group with good crystallinity, plus the monoclinic $C 2 / m$ phase $\left(\mathrm{Li}_{2} \mathrm{MnO}_{3}\right)$. The as prepared samples were further characterized by SEM, TEM, HERTEM and Raman scattering. The best electrochemical properties were obtained with EDTA. This chelating agent not only leads to the lowest concentration of $\mathrm{Ni}^{2+}-\mathrm{Li}^{+}$antisite defects, which results in enhanced capacity retention, but also minimizes the charge transfer resistance, which results in improved rate capability.

\section{References}

1. Ellis BL, Lee KT, Nazar LF (2010) Positive electrode materials for Li-ion and Li batteries. Chem Mater 22:691-714 
2. Julien CM, Mauger A, Vijh A, Zaghib K (2016) Lithium Batteries: Science and Technology. Springer, Cham, Switzerland

3. Dai D, Li B, Tang H, Chang K, Jiang K, Chang Z, Yuan X (2016) Simultaneously improved capacity and initial coulombic efficiency of Li-rich cathode $\mathrm{Li}\left[\mathrm{Li}_{0.2} \mathrm{Mn}_{0.54} \mathrm{Co}_{0.13} \mathrm{Ni}_{0.13}\right] \mathrm{O}_{2}$ by enlarging crystal cell from a nanoplate precursor. $\mathrm{J}$ Power Sources 307:665-672

4. Yu HJ, Zhou HS (2013) High-energy cathode materials $\left(\mathrm{Li}_{2} \mathrm{MnO}_{3}-\mathrm{LiMO}_{2}\right)$ for lithium-ion batteries. J Phys Chem Lett 4:1268-1280

5. Thackeray MM, Kang SH, Johnson CS, Vaughey JT, Benedek R, Hackney SA (2007) $\mathrm{Li}_{2} \mathrm{MnO}_{3}$-stabilized $\mathrm{LiMO}_{2}(\mathrm{M}=\mathrm{Mn}, \mathrm{Ni}, \mathrm{Co})$ electrodes for lithium-ion batteries. $\mathrm{J}$ Mater Chem 17:3112-3125

6. He P, Yu HJ, Li D, Zhou HS (2012) Layered lithium transition metal oxide cathodes towards high energy lithium-ion batteries. J Mater Chem 22:3680-3695

7. Bai Y, Li Y, Zhong YX, Chen S, Wu F, Wu C (2014) Li-rich transition metal oxide $\mathrm{xLi}_{2} \mathrm{MnO}_{3} \cdot(1-\mathrm{x}) \mathrm{LiMO}_{2}(\mathrm{M}=\mathrm{Ni}, \mathrm{Co}$ or $\mathrm{Mn})$ for lithium ion batteries. Prog Chem 26:259-269

8. Abdel-Ghany AE, Hashem AM, Elzahany EA, Abuzeid HA, Indris S, Nikolowski K, Ehrenberg H, Zaghib K, Mauger A, Julien CM (2016) Structural properties and application in lithium cells of $\mathrm{Li}\left(\mathrm{Ni}_{0.5} \mathrm{Co}_{0.5}\right)_{1-\mathrm{y}} \mathrm{Fe}_{\mathrm{y}} \mathrm{O}_{2}(0 \leq \mathrm{y} \leq 0.25)$ prepared by sol-gel route: doping optimization. J Power Sources 320:168-179

9. Hashem AM, El-Taweel RS, Abuzeid HM, Abdel-Ghany AE, Eid AE, Groult H, Mauger A, Julien CM (2012) Structural and electrochemical properties of $\mathrm{LiNi}_{1 / 3} \mathrm{Co}_{1 / 3} \mathrm{Mn}_{1 / 3} \mathrm{O}_{2}$ material prepared by a two-step synthesis via oxalate precursor. Ionics 18:1-9

10. Abdel-Ghany AE, Mauger A, Groult H, Julien CM (2012) Magnetic properties of $\mathrm{LiNi} 0.5 \mathrm{Mn}_{0.47} \mathrm{Al}_{0.03} \mathrm{O}_{2}$ as positive electrode for $\mathrm{Li}$-ion batteries. Ionics 18:241-247

11. Zhao T, Chen S, Li L, Zhang X, Chen R, Belharouak I, Wu F, Amine K (2013) Synthesis, characterization, and electrochemistry of cathode material 
$\mathrm{Li}\left[\mathrm{Li}_{0.2} \mathrm{Co}_{0.13} \mathrm{Ni}_{0.13} \mathrm{Mn}_{0.54}\right] \mathrm{O}_{2}$ using organic chelating agents for lithium-ion batteries. J Power Sources 228:206-213

12. Armstrong AR, Holzapfel M, Novak P, Johnson CS, Kang SH, Thackeray MM, Bruce PG (2006) Demonstrating oxygen loss and associated structural reorganization in the lithium battery cathode $\mathrm{Li}\left[\mathrm{Ni}_{0.2} \mathrm{Li}_{0.2} \mathrm{Mn}_{0.6}\right] \mathrm{O}_{2}$. J Am Chem Soc 128:8694-8698

13. Zhang X, Porras-Gutierrez AG, Mauger A, Groult H, Julien CM (2017) Nanotechnology of positive electrodes for Li-ion batteries. Inorganics (Basel) 5:25

14. Wu Y, Murugan AV, Manthiram A (2008) Surface modification of high capacity layered $\mathrm{Li}\left[\mathrm{Li}_{0.2} \mathrm{Mn}_{0.54} \mathrm{Ni}_{0.13} \mathrm{Co}_{0.13}\right] \mathrm{O}_{2}$ cathodes by $\mathrm{AlPO}_{4}$. J Electrochem Soc 155:A635-A641

15. Abdel-Ghany A, El-Tawil RS, Hashem AM, Julien CM (2019) Improved electrochemical performance of $\mathrm{LiNi}_{0.5} \mathrm{Mn}_{0.5} \mathrm{O}_{2}$ by Li-enrichment and $\mathrm{AlF}_{3}$ coating. Materialia 5:100207

16. Li CD, Xu J, Xia JS, Liu W, Xiong X, Zheng ZA (2016) Influence of $\mathrm{FeF}_{3}$ coating layer on the electrochemical properties of $\mathrm{Li}\left[\mathrm{Li}_{0.2} \mathrm{Mn}_{0.54} \mathrm{Ni}_{0.13} \mathrm{Co}_{0.13}\right] \mathrm{O}_{2}$ cathode materials for lithium-ion batteries, Solid State Ionics 292 75-82

17. He H, Zan L, Zhang $\mathrm{Y}$ (2016) Effects of amorphous $\mathrm{V}_{2} \mathrm{O}_{5}$ coating on the electrochemical properties of $\mathrm{Li}\left[\mathrm{Li} 0.2 \mathrm{Mn}_{0.54} \mathrm{Ni}_{0.13} \mathrm{Co}_{0.13}\right] \mathrm{O}_{2}$ as cathode material for $\mathrm{Li}$ ion batteries. J Alloys Compd 680:95-104

18. Wu Y, Manthiram A (2006) High capacity, surface-modified layered $\mathrm{Li}\left[\mathrm{Li}_{(1-\mathrm{x}) 3} \mathrm{Mn}_{(2-\mathrm{x}) 3} \mathrm{Ni}_{x_{3}} \mathrm{Co}_{x_{3}}\right] \mathrm{O}_{2}$ cathodes with low Irreversible capacity loss. Electrochem Solid State Lett 9:A221-A224

19. Kang SH, Johnson CS, Vaughey JT, Amine K, Thackeray MM (2006) The effects of acid treatment on the electrochemical properties of $0.5 \mathrm{Li}_{2} \mathrm{MnO}_{3} \cdot 0.5 \mathrm{LiNi}_{0.44} \mathrm{Co}_{0.25} \mathrm{Mn}_{0.31} \mathrm{O}_{2}$ electrodes in lithium cells. J Electrochem Soc 153:A1186-A1196

20. Liu B, Zhang Z, Wu M, Xu S (2018) Effects of citric acid treatment on the electrochemical properties of $\mathrm{Li}_{1.2} \mathrm{Mn}_{0.54} \mathrm{Ni}_{0.13} \mathrm{Co}_{0.13} \mathrm{O}_{2}$ cathode material. Int $\mathrm{J}$ Electrochem Sci 13:7578-7589 
21. Zheng J, Deng S, Shi Z, Xu H, Xu H, Deng Y, Zhang Z, Chen G (2013) The effects of persulfate treatment on the electrochemical properties of $\mathrm{Li}\left[\mathrm{Li}_{0.2} \mathrm{Mn}_{0.54} \mathrm{Ni}_{0.13} \mathrm{Co}_{0.13}\right] \mathrm{O}_{2}$ cathode material. J Power Sources 221:108-113

22. Yu DYW, Yanagida K, Nakamura H (2010) Surface modification of Li-excess Mnbased cathode materials. J Electrochem Soc 157:A1177-A1182

23. Zheng Y, Chen L, Su Y, Tan J, Bao L, Lu Y, Wang J, Chen R, Chen S, Wu F (2017) An interfacial framework for breaking through the Li-ion transport barrier of $\mathrm{Li}$-rich layered cathode materials. J Mater Chem A 5:24292-24298

24. Wang MJ, Shao AF, Yu FD, Sun G, Gu DM, Wang ZB (2019) Simple water treatment strategy to optimize the $\mathrm{Li}_{2} \mathrm{MnO}_{3}$ activation of lithium-rich cathode materials. ACS Sustainable Chem Eng 7:12825-12837

25. Guo H, Wei Z, Jia K, Qiu B, Yin C, Meng F, Zhang Q, Gu L, Han S, Liu Y, Zhao H, Jiang W, Cui H, Xia Y, Liu Z (2019) Abundant nanoscale defects to eliminate voltage decay in Li-rich cathode materials. Energy Storage Mater 16:220-227

26. Robertson AD, Bruce PG (2002) The Origin of Electrochemical Activity in $\mathrm{Li}_{2} \mathrm{MnO}_{3}$. Chem Commun 23:2790-2791

27. Armstrong AR, Robertson AD, Bruce PG (2005) Overcharging manganese oxides: extracting lithium beyond $\mathrm{Mn}^{4+}$. J Power Sources 146:275-280

28. Amalraj F, Kovacheva D, Talianker M, Zeiri L, Grinblat J, Leifer N, Goobes G, Markovsky B, Aurbach D (2010) Synthesis of integrated cathode materials $x \mathrm{Li}_{2} \mathrm{MnO}_{3} \cdot(1-x) \mathrm{LiMn}_{1 / 3} \mathrm{Ni}_{1 / 3} \mathrm{Co}_{1 / 3} \mathrm{O}_{2} \quad(x=0.3, \quad 0.5,0.7)$ and studies of their electrochemical behaviour. J Electrochem Soc 157:A1121-A1130

29. Zheng JM, Wu XB, Yang Y (2011) A comparison of preparation methods on the electrochemical performance of cathode material $\mathrm{Li}\left[\mathrm{Li}_{0.2} \mathrm{Mn}_{0.54} \mathrm{Ni}_{0.13} \mathrm{Co}_{0.13}\right] \mathrm{O}_{2}$ for lithium ion battery. Electrochim Acta 56:3071-3078

30. Zhang LJ, Wu B, Li N, Wu F (2014) Hierarchically porous micro-rod lithium-rich cathode material $\mathrm{Li}_{1.2} \mathrm{Ni}_{0.13} \mathrm{Mn}_{0.54} \mathrm{Co}_{0.13} \mathrm{O}_{2}$ for high performance lithium-ion batteries. Electrochim Acta 118:67-74 
31. Li L, Xu M, Chen Z, Zhou X, Zhang Q, Zhu H, Wu C, Zhang K (2015) Highperformance lithium-rich layered oxide materials: Effects of chelating agents on microstructure and electrochemical properties. Electrochim. Acta 174:446-455

32. Wu Y, Manthiram A (2006) High capacity, surface-modified layered $\mathrm{Li}\left[\mathrm{Li}_{(1-\mathrm{x})} \mathrm{Mn}_{(2-\mathrm{x}) 3} \mathrm{Ni}_{x_{3}} \mathrm{Co}_{\mathrm{x}_{3}}\right] \mathrm{O}_{2}$ cathodes with low Irreversible capacity loss. Electrochem Solid State Lett 9:A221-A224

33. Johnson CS, Li N, Lefief C, Thackeray MM (2007) Anomalous capacity and cycling stability of $x \mathrm{Li}_{2} \mathrm{MnO}_{3} \cdot(1-x) \mathrm{LiMO}_{2}$ electrodes $(\mathrm{M}=\mathrm{Mn}, \mathrm{Ni}, \mathrm{Co})$ in lithium batteries at $50{ }^{\circ} \mathrm{C}$. Electrochem Commun 9:787-795

34. Zhang JW, Guo X, Yao SM, Zhu WT, Gao XP (2013) Tailored synthesis of $\mathrm{Ni}_{0.25} \mathrm{Mn}_{0.75} \mathrm{CO}_{3}$ spherical precursors for high capacity Li-rich cathode materials via a urea-based precipitation method. J Power Sources 238:245-250

35. Zhao CH, Wang XX, Liu R, Xu FF, Shen Q (2014) $\beta-\mathrm{MnO}_{2}$ sacrificial template synthesis of $\mathrm{Li}_{1.2} \mathrm{Ni}_{0.13} \mathrm{Co}_{0.13} \mathrm{Mn}_{0.54} \mathrm{O}_{2}$ for lithium ion battery cathodes. RSC Adv 4:7154-7159

36. Cheng FQ, Xin YL, Chen JT, Lu L, Zhang XX, Zhou HH (2013) Mono-disperse $\mathrm{Li}_{1.2} \mathrm{Mn}_{0.6} \mathrm{Ni}_{0.2} \mathrm{O}_{2}$ spheres with enhanced lithium storage capability. J Mater Chem A $1: 5301-5308$

37. Zhao C, Shen Q (2014) Organic acid assisted solid-state synthesis of $\mathrm{Li}_{1.2} \mathrm{Ni}_{0.16} \mathrm{Co}_{0.08} \mathrm{Mn}_{0.56} \mathrm{O}_{2}$ nanoparticles as lithium ion battery cathodes. Current Appl Phys 14:1849-1853

38. Shi SJ, Tu JP, Tang YY, Liu XY, Zhao XY, Wang XL, Gu CD (2013) Morphology and electrochemical performance of $\mathrm{Li}\left[\mathrm{Li}_{1.2} \mathrm{Mn}_{0.54} \mathrm{Ni}_{0.13} \mathrm{Co}_{0.13}\right] \mathrm{O}_{2}$ cathode materials treated in molten salt. J Power Source 241:186-195

39. Zhong ZH, Ye NQ, Wang H, Ma Z (2011) Low temperature combustion synthesis and performance of spherical $0.5 \mathrm{Li}_{2} \mathrm{MnO}_{3}-\mathrm{LiNi}_{0.5} \mathrm{Mn}_{0.5} \mathrm{O}_{2}$ cathode material for $\mathrm{Li}$ ion batteries. Chem Eng J 175:579-584 
40. Liao D, Xia C, Xi X, Zhou C, Ciao K, Chen X, Qin S (2017) Sol-gel preparation of Li-rich layered cathode material for lithium ion battery with polymer polyacrylic acid + citric acid chelators. J Sol Gel Sci Technol 78:403-410

41. O'Brien LC, Root HB, Wei CH, Jensen D, Shabestary N, De Meo C, Eder DJ (2015) $\mathrm{M}^{2+}$ EDTA binding Affinities: A modern experiment in thermodynamics for the physical chemistry laboratory. J Chem Educ 92:1547-1551

42. Yuan Z, Yue H, Zhang X, Deng X (2008) Preparation and characterization of $\mathrm{LiV}_{3} \mathrm{O}_{8}$ cathode material for lithium secondary batteries through an EDTA sol-gel method. Solid State Ionics 179 1763-1767

43. Dong P, Xia SB, Zhang YJ, Zhang YN, Qiu ZP, Yao Y (2017) Influence of complexing agent on the structure and electrochemical properties of $\mathrm{LiNi}_{0.80} \mathrm{Co}_{0.15} \mathrm{Al}_{0.05} \mathrm{O}_{2}$ cathode synthesized by sol-gel method: a comparative study. Int J Electrochem Sci 12:561-575

44. Li Y, Hong L, Sun J, Wu F, Chen S (2012) Electrochemical performance of $\mathrm{Li}_{3} \mathrm{~V}_{2}\left(\mathrm{PO}_{4}\right)_{3} / \mathrm{C}$ prepared with a novel carbon source, EDTA. Electrochim Acta $85: 110-115$

45. Zhang Y, Zhang C, Lin Y, Xiong DB, Wang D, Wu X, He D (2014) Influence of $\mathrm{Sc}^{3+}$ doping in $\mathrm{B}$-site on electrochemical performance of $\mathrm{Li}_{4} \mathrm{Ti}_{5} \mathrm{O}_{12}$ anode materials for lithium-ion battery. J Power Sources 250: 50-57

46. Wang CC, Lin YC, Chou PH (2015) Mitigation of layer to spinel conversion of a lithium rich layered oxide cathode by substitution of $\mathrm{Al}$ in a lithium ion battery. RSC Adv 5:68919-68928

47. Hashem AM, Abdel-Ghany AE, Abuzeid HM, El-Tawil RS, Indris S, Ehrenberg H, Mauger A, Julien, CM (2018) EDTA as chelating agent for sol-gel synthesis of spinel $\mathrm{LiMn}_{2} \mathrm{O}_{4}$ cathode material for lithium batteries. J Alloys Compd 737:758-766

48. Konishi H, Hirano T, Takamatsu D, Gunji A, Feng X, Furutsuki S, Takahashi S, Terada S (2017) Potential hysteresis between charge and discharge reactions in $\mathrm{Li}_{1.2} \mathrm{Ni}_{0.13} \mathrm{Mn}_{0.54} \mathrm{Co}_{0.13} \mathrm{O}_{2}$ for lithium ion batteries. Solid State Ionics 300:120-127 
49. Laisa CP, Nanda-Kumar AK, Chandrasekaran SS, Murugan P, Lakshminarasimhan N, Govindaraj R, Ramesha K (2016) A comparative study on electrochemical cycling stability of lithium rich layered cathode materials $\mathrm{Li}_{1.2} \mathrm{Ni}_{0.13} \mathrm{M}_{0.13} \mathrm{Mn}_{0.54} \mathrm{O}_{2}$ where $\mathrm{M}=$ Fe or Co. J Power Sources 324:462-474

50. Yan W, Jiang J, Liua W, Sun D, Zhao E, Jin Y, Kanamura K (2017) Effect of precipitators on the morphologies and electrochemical properties of $\mathrm{Li}_{1.2} \mathrm{Ni}_{0.13} \mathrm{Mn}_{0.54} \mathrm{Co}_{0.13} \mathrm{O}_{2}$ via rapid nucleation and post-solvothermal method. Electrochim Acta 224:161-170

51. Liu H, Wu YP, Rahm E, Holze R, Wu HQ (2004) Cathode materials of lithium ion batteries prepared by sol-gel methods. J Solid State Electrochem 8:450-466

52. Lim SH, Cho J (2008) PVP-assisted $\mathrm{ZrO}_{2}$ coating in $\mathrm{LiMn}_{2} \mathrm{O}_{4}$ spinel cathode nanoparticles prepared by $\mathrm{MnO}_{2}$ nanowire templates. Electrochem Commun 10:1478-1481

53. Abdel-Ghany A, Zaghib K, Gendron F, Mauger A, Julien CM (2006) Structural, magnetic and electrochemical properties of $\mathrm{LiNi}_{0.5} \mathrm{Mn}_{0.5} \mathrm{O}_{2}$ as positive electrode for Li-ion batteries. Electrochim Acta 52:4092-4100

54. Zhang L, Wu B, Li N, Mu D, Zhang C, Wu F (2013) Rod-like hierarchical nano/ micro $\mathrm{Li}_{1.2} \mathrm{Ni}_{0.2} \mathrm{Mn}_{0.6} \mathrm{O}_{2}$ as high performance cathode materials for lithium-ion batteries, J. Power Sources 240:644-652

55. Yuan X, Xu QJ, Wang C, Liu X, Liu H, Xia Y (2015) A facile and novel organic coprecipitation strategy to prepare layered cathode material $\mathrm{Li}\left[\mathrm{Li}_{0.2} \mathrm{Mn}_{0.54} \mathrm{Ni}_{0.13} \mathrm{Co}_{0.13}\right] \mathrm{O}_{2}$ with high capacity and excellent stability. J Power Sources 279:157-164

56. Bréger J, Jiang M, Dupré N, Meng YS, Shao-Horn Y, Ceder G, Grey CP (2005) High-resolution X-ray diffraction, DIFFaX, NMR and first principles study of disorder in the $\mathrm{Li}_{2} \mathrm{MnO}_{3}-\mathrm{Li}\left[\mathrm{Ni}_{1 / 2} \mathrm{Mn}_{1 / 2}\right] \mathrm{O}_{2}$ solid solution. J Solid State Chem $178: 2575-2585$

57. Boulineau A, Croguennec L, Delmas C, Weill F (2009) Reinvestigation of $\mathrm{Li}_{2} \mathrm{MnO}_{3}$ structure: electron diffraction and high resolution TEM. Chem Mater 21:4216-4222 
58. Jarvis K, Deng Z, Allard LF, Manthiram A, Ferreira P (2011) Atomic structure of a lithium-rich layered oxide material for lithium-ion batteries: evidence of a solid solution. Chem Mater 23:3614-3621

59. Jarvis KA, Deng Z, Allard LF, Manthiram A, Ferreira PJ (2012) Understanding structural defects in lithium-rich layered oxide cathodes. J Mater Chem 22:11550-11555

60. Ohzuku T, Ueda A, Nagayama M (1993) Electrochemistry and structural chemistry of $\mathrm{LiNiO}_{2}$ (R-3m) for 4 volt secondary lithium cells. J Electrochem Soc 140:1862-1870

61. Morales J, Peres-Vicente C, Tirado JL (1990) Cation distribution and chemical deintercalation of $\mathrm{Li}_{1 \times} \mathrm{Ni}_{1+\mathrm{x}} \mathrm{O}_{2}$. Mater Res Bull 25:623-630

62. Dahn JR, von Sacken U, Michal CA (1990) Structure and electrochemistry of $\mathrm{Li}_{1 \pm y} \mathrm{NiO}_{2}$ and a new $\mathrm{Li}_{2} \mathrm{NiO}_{2}$ phase with the $\mathrm{Ni}(\mathrm{OH})_{2}$ structure. Solid State Ionics 44:87-97

63. Reimers JN, Rossen E, Jones CD, Dahn JR (1993) Structure and electrochemistry of $\mathrm{Li}_{\mathrm{x}} \mathrm{Fe}_{\mathrm{y}} \mathrm{Ni}_{1-\mathrm{y}} \mathrm{O}_{2}$. Solid State Ionics 61:335-344

64. Bareno J, Balasubramanian M, Kang SH, Wen JG, Lei CH, Pol SV, Petrov I, Abraham DP (2011) Long-range and local structure in the layered oxide $\mathrm{Li}_{1.2} \mathrm{Co}_{0.4} \mathrm{Mn}_{0.4} \mathrm{O}_{2}$. Chem Mater 23:2039-2050

65. Thackeray MM, Johnson CS, Vaughey JT, Li N, Hackney SA (2005) Advances in manganese-oxide composite electrodes for lithium-ion batteries. J Mater Chem $15: 2257-2267$

66. D. Mohanty, S. Kalnaus, R. A. Meisner, K. J. Rhodes, J. Li, E. A. Payzant, D. L. Wood III, C. Daniel, (2013) Structural transformation of a lithium-rich $\mathrm{Li}_{1.2} \mathrm{Co}_{0.1} \mathrm{Mn}_{0.55} \mathrm{Ni}_{0.15} \mathrm{O}_{2}$ cathode during high voltage cycling resolved by in situ $\mathrm{X}$ ray diffraction, J. Power Sources 229: 239-248

67. Gabrisch H, Yi T, Yazami R (2008) Transmission electron microscope studies of $\mathrm{LiNi}_{1 / 3} \mathrm{Mn}_{1 / 3} \mathrm{Co}_{1 / 3} \mathrm{O}_{2}$ before and after long-term aging at $70{ }^{\circ} \mathrm{C}$. Electrochem Solid State Lett 11:A119-A124 
68. Mohanty D, Gabrisch H (2012) Microstructural investigation of $\mathrm{Li}_{\mathrm{x}} \mathrm{Ni}_{1 / 3} \mathrm{Mn}_{1 / 3} \mathrm{Co}_{1 / 3} \mathrm{O}_{2}$ $(\mathrm{x} \leq 1)$ and its aged products via magnetic and diffraction study. J Power Sources $220: 405-412$

69. Julien C, Camacho-Lopez MA, Mohan T, Chitra S, Kalyani P, Gopukumar S (2000) Combustion synthesis and characterization of substituted lithium cobalt oxides in lithium batteries. Solid State Ionics135:241-248

70. Julien C, Massot M (2002) Raman scattering of $\mathrm{LiNi}_{1-y} \mathrm{Al}_{\mathrm{y}} \mathrm{O}_{2}$. Solid State Ionics $148: 53-59$

71. Park KS, Song CH, Stephan AM, Jeong SK, Nahm KS, Oh SM, Kim YG (2006) Influence of solvents on the synthesis and electrochemical properties of $\mathrm{Li}\left[\mathrm{Li}_{1 / 5} \mathrm{Ni}_{1 / 10} \mathrm{Co}_{1 / 5} \mathrm{Mn}_{1 / 2}\right] \mathrm{O}_{2}$ for the applications in lithium-ion batteries. J Mater Sci $41: 7628-7635$

72. Liu J, Hou M, Yi J, Guo S, Wang C, Xia Y (2014) Improving the electrochemical performance of layered lithium-rich transition-metal oxides by controlling the structural defects. Energy Environ Sci 7:705-714

73. Li Z, Du F, Bie X, Zhang D, Cai Y, Cui X, Wang C, Chen G, Wei Y (2010) Electrochemical kinetics of the $\mathrm{Li}\left[\mathrm{Li}_{0.23} \mathrm{Co}_{0.3} \mathrm{Mn}_{0.47}\right] \mathrm{O}_{2}$ cathode material studied by GITT and EIS. J Phys Chem C 114:22751-22757

74. Hashem AMA, Abdel-Ghany AE, Eid AE, Trottier J, Zaghib K, Mauger A, Julien $\mathrm{CM}$ (2011) Study of the surface modification of $\mathrm{LiNi}_{1 / 3} \mathrm{Co}_{1 / 3} \mathrm{Mn}_{1 / 3} \mathrm{O}_{2}$ cathode material for lithium ion battery. J Power Sources 196:8632-8637

75. Yu DYW, Yanagida K (2011) Structural analysis of $\mathrm{Li}_{2} \mathrm{MnO}_{3}$ and related Li-Mn-O materials. J Electrochem Soc 158:A1015-A1022

76. Venkateswara-Rao C, Soler J, Katiyar R, Shojan J, West WC, Katiyar RS (2014) Investigations on electrochemical behavior and structural stability of $\mathrm{Li}_{1.2} \mathrm{Mn}_{0.54} \mathrm{Ni}_{0.13} \mathrm{Co}_{0.13} \mathrm{O}_{2}$ lithium-iIon cathodes via in-situ and ex-situ Raman spectroscopy. J Phys Chem C 118:14133-14141 
77. Zheng Y, Chen L, Su Y, Tan J, Bao L, Lu Y, Wang J, Chen R, Chen S, Wu F (2017) An interfacial framework for breaking through the Li-ion transport barrier of $\mathrm{Li}$-rich layered cathode materials. J Mater Chem A 5: 24292-24298

78. Johnson CS, Kim JS, Lefief C, Li N, Vaughey JT, Thackeray MM (2004) The significance of the $\mathrm{Li}_{2} \mathrm{MnO}_{3}$ component in composite $\mathrm{xLi}_{2} \mathrm{MnO}_{3} \cdot(1 \mathrm{x}) \mathrm{LiMn}_{0.5} \mathrm{Ni}_{0.5} \mathrm{O}_{2}$ electrodes. Electrochem Commun 6:108. 5-1091

79. Du K, Huang X, Hu GR, Peng ZD (2012) Synthesis and electrochemical properties of $\mathrm{Li}\left[\mathrm{Li}_{0.2} \mathrm{Ni}_{0.2} \mathrm{Mn}_{0.6}\right] \mathrm{O}_{2}$ as high capacity cathode material. Trans Nonferrous Met Soc China 22:1201-1208

80. Lu Z, Dahn JR (2002) Understanding the anomalous capacity of $\mathrm{Li} / \mathrm{Li}\left[\mathrm{Ni}_{x} \mathrm{Li}_{(1 / 3-2 \times /}\right.$ $\left.\left.{ }_{3}\right) \mathrm{Mn}_{(2 / 3-\mathrm{x} / 3)}\right] \mathrm{O}_{2}$ cells using in situ X-ray diffraction and electrochemical studies. $\mathrm{J}$ Electrochem Soc 149:A815-A822

81. Shen CH, Wang Q, Fu F, Huang L, Lin Z, Shen SY, Su H, Zhang XM, Xu BB, Li GT, Sun SG (2014) Facile synthesis of the Li-rich layered oxide $\mathrm{Li}_{1.23} \mathrm{Ni}_{0.09} \mathrm{Co}_{0.12} \mathrm{Mn}_{0.56} \mathrm{O}_{2}$ with superior lithium storage performance and new insights into structural transformation of the layered oxide material during chargedischarge cycle: in situ XRD characterization. ACS Appl Mater Interfaces 23:5516-5524

82. Armstrong AR, Holzapfel M, Novak P, Johnson CS, Kang SH, Thackeray MM, Bruce PG (2006) Demonstrating oxygen loss and associated structural reorganization in the lithium battery cathode $\mathrm{Li}\left[\mathrm{Ni}_{0.2} \mathrm{Li}_{0.2} \mathrm{Mn}_{0.6}\right] \mathrm{O}_{2}$. J Am Chem Soc 128:8694-8698

83. Croy JR, Kim D, Balasubramanian M, Gallagher K, Kang SH, Thackeray MM (2012) Countering the voltage decay in high capacity $\mathrm{xLi}_{2} \mathrm{MnO}_{3} \cdot(1-\mathrm{x}) \mathrm{LiMO}_{2}$ electrodes ( $\mathrm{M}=\mathrm{Mn}, \mathrm{Ni}, \mathrm{Co})$ for $\mathrm{Li}^{+}$-ion batteries. J Electrochem Soc 159:A781-A790

84. Johnson CS, Li N, Lefief C, Vaughey JT, Thackeray MM (2008) Synthesis, characterization and electrochemistry of lithium battery electrodes: $\mathrm{xLi}_{2} \mathrm{MnO}_{3} \cdot(1-$ $\mathrm{x}) \mathrm{LiMn}_{0.333} \mathrm{Ni}_{0.333} \mathrm{Co}_{0.333} \mathrm{O}_{2}(0 \leq x \leq 0.7)$. Chem Mater 20:6095-6106 
85. Croy JR, Balasubramanian M, Gallagher KG, Burrell AK (2015) Review of the U.S. Department of Energy's "Deep Dive" effort to understand voltage fade in Li- and Mn-rich cathodes. Acc Chem Res 48:2813-2821

86. Mohanty D, Li J, Abraham DP, Huq A, Payzant AE, Wood III DL, Daniel C (2014) Unraveling the voltage-fade mechanism in high-energy-density lithium-ion batteries: Origin of the tetrahedral cations for spinel conversion. Chem Mater 26:6272-6280

87. Croy JR, Gallagher KG, Balasubramanian M, Long BR, Thackeray MM (2014) Quantifying hysteresis and voltage fade in $\mathrm{xLi}_{2} \mathrm{MnO}_{3} \cdot(1-\mathrm{x}) \mathrm{LiMn}_{0.5} \mathrm{Ni}_{0.5} \mathrm{O}_{2}$ electrodes as a function of $\mathrm{Li}_{2} \mathrm{MnO}_{3}$ content. J Electrochem Soc 161:A318-A325

88. Hong J, Seo DH, Kim SW, Gwon H, Oh ST, Kang K (2010) Structural evolution of layered $\mathrm{Li}_{1.2} \mathrm{Ni}_{0.2} \mathrm{Mn}_{0.6} \mathrm{O}_{2}$ upon electrochemical cycling in a Li rechargeable battery. $\mathrm{J}$ Mater Chem 20:10179-10186

89. Gu M, Belharouak I, Zheng J, Wu H, Xiao J, Genc A, Amine K, Thevuthasan S, Baer DR, Zhang, JG (2013) Formation of the spinel phase in the layered composite cathode used in Li-ion batteries. ACS Nano 7:760-767

90. Yan P, Nie A, Zheng J, Zhou Y, Lu D, Zhang X, Xu R, Belharouak I, Zu X, Xiao J, Amine K, Liu J, Gao F, Shahbazian-Yassar R, Zhang, JG, Wang, CM (2015) Evolution of lattice structure and chemical composition of the surface reconstruction layer in $\mathrm{Li}_{1.2} \mathrm{Ni}_{0.2} \mathrm{Mn}_{0.6} \mathrm{O}_{2}$ cathode material for lithium ion batteries. Nano Lett $15: 514-522$

91. Abdullah NA, Hasan S, Osman N (2013) Role of CA-EDTA on the synthesizing process of cerate-zirconate ceramics electrolyte. J Chem 908340

92. Tao Y, Shao J, Wang J, Wang WG (2008) Synthesis and properties of $\mathrm{La}_{0.6} \mathrm{Sr}_{0.4} \mathrm{CoO}_{3-\delta}$ nanopowder. J Power Sources 185:609-614

93. Zhang X, Jiang WJ, Mauger A, Qilu, Gendron F, Julien CM (2010) Minimization of the cation mixing in $\mathrm{Li}_{1+\mathrm{x}}(\mathrm{NMC})_{1-\mathrm{x}} \mathrm{O}_{2}$ as cathode material. $\mathrm{J}$ Power Sources $195: 1292-1301$ 